\title{
Spatial and temporal variations in basal melting at Nivlisen ice shelf, East Antarctica, derived from phase-sensitive radars
}

\author{
Katrin Lindbäck ${ }^{1}$, Geir Moholdt ${ }^{1}$, Keith W. Nicholls ${ }^{2}$, Tore Hattermann ${ }^{1}$, Bhanu Pratap ${ }^{3}$, Meloth Thamban ${ }^{3}$, and \\ Kenichi Matsuoka ${ }^{1}$ \\ ${ }^{1}$ Norwegian Polar Institute, Framsenteret, Postboks 6606, Langnes, 9296 Troms $\varnothing$, Norway \\ ${ }^{2}$ British Antarctic Survey, Natural Environment Research Council, High Cross, Madingley Rd, Cambridge CB3 0ET, UK \\ ${ }^{3}$ National Centre for Polar and Ocean Research, Ministry of Earth Sciences, Government of India, Headland Sada, \\ Vasco-da-Gama, Goa 403 804, India
}

Correspondence: Katrin Lindbäck (katrin.lindback@npolar.no)

Received: 13 May 2019 - Discussion started: 24 May 2019

Revised: 8 August 2019 - Accepted: 15 August 2019 - Published: 2 October 2019

\begin{abstract}
Thinning rates of ice shelves vary widely around Antarctica, and basal melting is a major component of ice shelf mass loss. In this study, we present records of basal melting at a unique spatial and temporal resolution for East Antarctica, derived from autonomous phase-sensitive radars. These records show spatial and temporal variations of basal melting in 2017 and 2018 at Nivlisen, an ice shelf in central Dronning Maud Land. The annually averaged basal melt rates are in general moderate $\left(\sim 0.8 \mathrm{~m} \mathrm{yr}^{-1}\right)$. Radar profiling of the ice shelf shows variable ice thickness from smooth beds to basal crevasses and channels. The highest basal melt rates $\left(3.9 \mathrm{~m} \mathrm{yr}^{-1}\right)$ were observed close to a grounded feature near the ice shelf front. Daily time-varying measurements reveal a seasonal melt signal $4 \mathrm{~km}$ from the ice shelf front, at an ice draft of $130 \mathrm{~m}$, where the highest daily basal melt rates occurred in summer (up to $5.6 \mathrm{~m} \mathrm{yr}^{-1}$ ). In comparison with wind, air temperatures, and sea ice cover from reanalysis and satellite data, the seasonality in basal melt rates indicates that summer-warmed ocean surface water was pushed by wind beneath the ice shelf front. We observed a different melt regime $35 \mathrm{~km}$ into the ice shelf cavity, at an ice draft of $280 \mathrm{~m}$, with considerably lower basal melt rates (annual average of $0.4 \mathrm{~m} \mathrm{yr}^{-1}$ ) and no seasonality. We conclude that warm deep-ocean water at present has a limited effect on the basal melting of Nivlisen. On the other hand, a warming in surface waters, as a result of diminishing sea ice cover, has the potential to increase basal melting near the ice shelf front. Continuous in situ monitoring of Antarctic ice shelves
\end{abstract}

is needed to understand the complex mechanisms involved in ice shelf-ocean interactions.

\section{Introduction}

The Antarctic contribution to global sea level rise has increased by a factor of 5 in the past two decades (IMBIE Team, 2018). Over $80 \%$ of the grounded ice in Antarctica drains out into floating ice shelves (Dupont and Alley, 2005). The thinning rates of these ice shelves vary widely around the continent (Paolo et al., 2015). The mass balance of an ice shelf is the sum of the ice gain and loss; ice gain comprises the advective input from ice across the grounding zone (where ice detaches from the bed and becomes afloat), snow accumulation, and marine-ice accretion. Ice loss encompasses surface melting and sublimation, basal melting from the ocean underneath the floating ice shelf, and iceberg calving at the ice front (Bamber et al., 2018). A negative mass balance can affect ice shelf stability, where a net mass loss reduces back stresses on grounded ice upstream, leading the tributaries to flow faster (Reese et al., 2018). Understanding controls on the mass balance of ice shelves around Antarctica is therefore the key to gaining a better understanding of the continent's present and future contribution to global sea level rise.

Iceberg calving occurs irregularly in time and can have dramatic effects on ice shelf mass balance when it occurs (Hogg and Gudmundsson, 2017). At present, iceberg calv- 
ing comprises approximately half of the mass loss from the Antarctic Ice Sheet, while the other half comes from basal melting (Depoorter et al., 2013; Rignot et al., 2013). Basal melting is not uniform and depends on the ocean properties in the vicinity of the ice shelf and the topography of both the ocean bed and the ice shelf base. Jacobs et al. (1992) described how different water masses can melt the ice shelf from below.

In mode 1 , ocean water with temperatures at the surface freezing point provides heat for melting deeper parts of the ice base because the pressure melting point of the ice is decreased to lower temperatures at depth. Basal melting at the deep grounding zones can be high and often occur at basal channels (e.g. $22 \mathrm{~m} \mathrm{yr}^{-1}$ for Ross Ice Shelf; Marsh et al., 2016); however, substantial marine-ice accretion reduces the net melting below these large ice shelves when the rising melt plume from the grounding zone super-cools and refreezes on the ice shelf base at shallower depths (Joughin and Vaughan, 2004). Since these cold shelf waters provide a limited source of ocean heat (Darelius and Sallée, 2017), average basal melt rates are often low for the largest ice shelves (e.g. $0.3 \mathrm{~m} \mathrm{yr}^{-1}$ for Ronne Ice Shelf; Rignot et al., 2013).

In mode 2, ice shelves melt from the presence of warm circumpolar deep-water intrusion (Jacobs et al., 1992). The rapid retreat and high thinning rates of glaciers in Antarctica have been attributed to the presence of warm circumpolar deep water below ice shelves in the Amundsen Sea sector of West Antarctica (Pritchard et al., 2012; Rignot et al., 2013). Circumpolar deep water surrounds the Antarctic continent, flowing clockwise with the Antarctic Circumpolar Current and is abundant near the continental shelf of West Antarctica. Circumpolar deep water accesses the deep bases of ice shelves directly through cross-continental submarine troughs, causing the higher basal melt rates; for example, Rignot et al. (2013) found Pine Island Ice Shelf to have an average melt rate of $16 \mathrm{~m} \mathrm{yr}^{-1}$. In East Antarctica, basal melting has been linked to circumpolar deep-water intrusion only at Totten Ice Shelf, where annual basal melt rates reached $\sim 11 \mathrm{~m} \mathrm{yr}^{-1}$ (Rignot et al., 2013; Rintoul et al., 2016). Farther west, in the Weddell Sea sector a cooler modified version of circumpolar deep water is advected along the coast (Dong et al., 2016; Ryan et al., 2016).

In mode 3, ice shelves can melt at shallow depths in the vicinity of their ice fronts when summer-warmed surface water is pushed by wind and tides under ice shelves (Jenkins and Doake, 1991; Makinson and Nicholls, 1999; Sverdrup, 1954; Zhou et al., 2014). Antarctic surface water has been observed under Ross Ice Shelf in West Antarctica (Malyarenko et al., 2019; Stern et al., 2013; Stewart et al., 2019) and at Fimbulisen in East Antarctica (Hattermann et al., 2012), suggesting it may be a more important process in basal melting than previously thought. Spatial patterns and relative magnitudes of all these three modes of basal melting remain largely unknown. Numerical modelling, however, indicates that the response of basal melting in the future strongly depends on the surface air warming (Kusahara and Hasumi, 2013). Future basal melting in Antarctica will therefore reflect the integrated response to changes in circumpolar deep-water temperatures and coastal processes that control its access to the continental shelf (Thompson et al., 2018). The detailed interplay of these processes today and in a future climate is still a major source of uncertainty when evaluating the response of the Antarctic Ice Sheet to climate change (Adusumilli et al., 2018).

In this study, we measured basal melting at Nivlisen $\left(70^{\circ} \mathrm{S}, 12^{\circ} \mathrm{E}\right)$ in central Dronning Maud Land, East Antarctica, using autonomous phase-sensitive radio echo sounders (ApRES; Fig. 1). Phase-sensitive radars use a technique where the phase of individual internal ice reflectors is tracked, yielding a time series of ice thickness change with high accuracy $(\sim 1 \mathrm{~mm})$ and short time intervals (Corr et al., 2002; Nicholls et al., 2015). This technique has been used to measure basal and englacial properties of ice at several locations around Antarctica (e.g. Davis et al., 2018; Jenkins et al., 2006; Marsh et al., 2016; Stewart et al., 2019) and in Greenland (Vaňková et al., 2018). Our objective is to study the spatial and temporal variations of basal melting and to interpret the results using (1) radar profiles of ice thickness, (2) in situ measured and satellite-derived or modelled ice flow speed and surface mass balance, and (3) atmospheric forcing from reanalysis data, sea ice distribution, and ocean tides. The data imply that different modes of basal melting are present at Nivlisen. Our in situ measured data of basal melting complement satellite-derived maps of spatially smoothed timeaveraged basal melt rates, and these will be a valuable data source for the validation of ice shelf and ocean models.

\section{Study area}

Dronning Maud Land covers a large area of East Antarctica, and its $2000 \mathrm{~km}$ long coast is characterized by extensive ice shelves interspersed with numerous ice rises and rumples (Fig. 1a). Ice rises are locations where the ice shelf flow is diverted around the grounded ice, and they are miniature ice caps with their own flow fields from the summit (Matsuoka et al., 2015). Ice rumples are smaller features that impose a disturbance on the ice shelf flow, causing the ice to thicken upstream with extensive crevassing. Individual ice shelves are relatively small, but they extend close to, or even beyond, the continental shelf break (Heywood et al., 1998). Basal melt rates from satellite data in Dronning Maud Land vary from nearly 0 to $7 \mathrm{~m} \mathrm{yr}^{-1}$ (2003 to 2008; Rignot et al., 2013). The interior of this region is partly separated by high mountains, causing steep ice surface slopes from the continental plateau towards the coastal areas (Howat et al., 2019). The drainage basin of Nivlisen $\left(27700 \mathrm{~km}^{2}\right)$, including the grounded ice that drains to the ice shelf, has an estimated potential of raising global sea level by $8 \mathrm{~cm}$ (Rignot et al., 2019). 


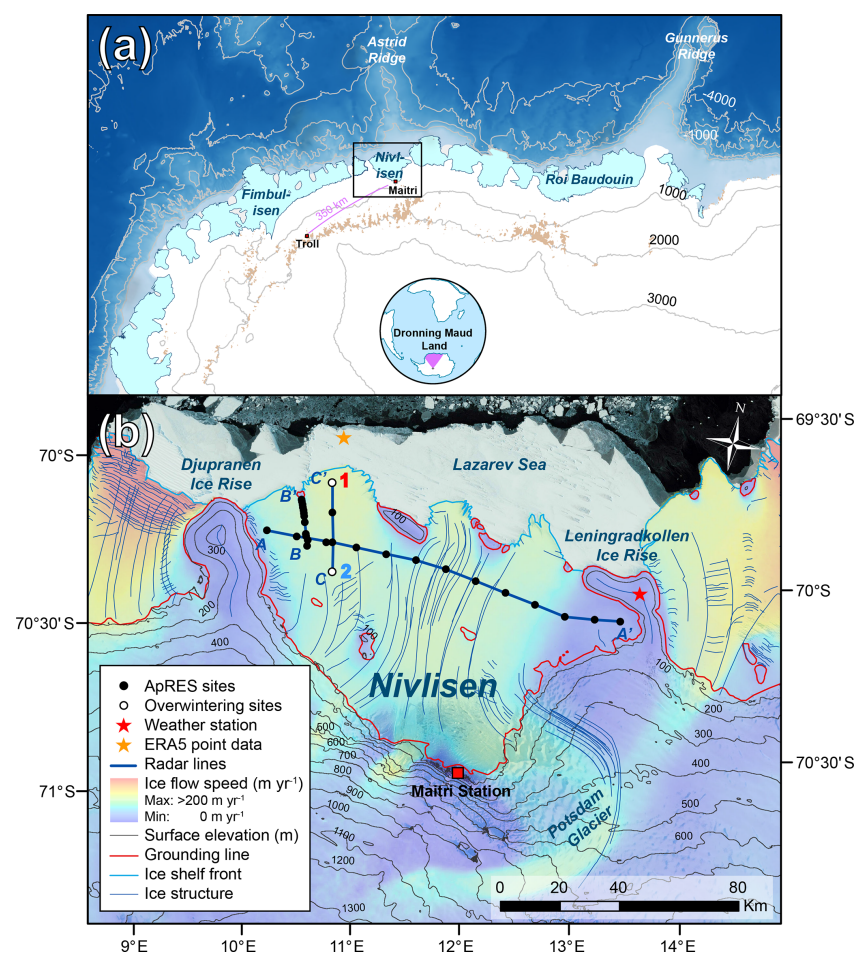

Figure 1. Study area. (a) Dronning Maud Land coast, with research stations (Troll and Maitri), ice shelves (light blue), and elevation contours with bathymetric features (Arndt et al., 2013). (b) Nivlisen with surrounding areas. Study sites, where ApRES and stakes for ice velocity and surface mass balance were located, ApRES overwintering sites (no. 1 called "seaward" and no. 2 called "landward"), and low-frequency radar profiles (A, B, and C). Satellitederived ice speed (Rignot et al., 2011), surface elevation (ma.s.l.; Howat et al., 2019), grounding line, ice shelf front (Mouginot et al., 2017), and ice structure (Goel et al., 2019) are also shown. Background image is Landsat image mosaic with sea ice in front of the ice shelf (Bindschadler et al., 2008). Grid coordinate system is WGS-84.

Nivlisen has an areal extent of $\sim 7300 \mathrm{~km}^{2}$ and forms a closed embayment between two larger promontory-type ice rises, Djupranen and Leningradkollen (Fig. 1b). Such grounded features are known to play vital roles in ice shelf and ice sheet dynamics over various timescales. For example, the un-grounding of an ice rumple within the ice shelves of Pine Island Glacier and Thwaites Glacier is thought to be a major cause of the ongoing rapid retreat and thinning (Favier et al., 2012; Gladstone et al., 2012; Jenkins et al., 2010). Bawden Ice Rise near the edge of Larsen C Ice Shelf helps maintain its stability, despite the collapse of the neighbouring Larsen A and B ice shelves (Borstad et al., 2013; Holland et al., 2015). Nivlisen is also grounded at a series of smaller ice rises and rumples near the present ice front, as well as at a few ice rumples in the middle of the ice shelf (Moholdt and Matsuoka, 2015). The bathymetry under the ice shelf is unknown.
The average ice shelf flow speed is $80 \mathrm{~m} \mathrm{yr}^{-1}$ (Rignot et al., 2011). Potsdam Glacier drains into Nivlisen from the southeast, with an average ice thickness of $\sim 1000 \mathrm{~m}$ (Fretwell et al., 2013) and ice flow speed of $\sim 50 \mathrm{~m} \mathrm{yr}^{-1}$ (Anschütz et al., 2007; Rignot et al., 2011). The satellitederived estimate of the grounding line flux for Nivlisen was $3.9 \pm 0.8 \mathrm{Gt} \mathrm{yr}^{-1}$ (2007-2008; Rignot et al., 2013). Elevated topography of the ice rises causes highly variable local climate and surface mass balance gradients (Lenaerts et al., 2014). In addition, Nivlisen has large surface mass balance transitions from being positive in the firn area near the ice front to being negative in the blue-ice area near the grounding zone, with increased wind erosion, evaporation, and sublimation owing to katabatic winds (Horwath et al., 2006). Near the grounding zone, summer surface melting is sufficient to form supraglacial lakes and streams that may occasionally drain through the ice shelf (Kingslake et al., 2015), making Nivlisen potentially sensitive to hydrofracturing (Lenaerts et al., 2017). Rignot et al. (2013) estimated the surface mass balance to be $1.8 \pm 0.3 \mathrm{Gt} \mathrm{yr}^{-1}$ (average 1979-2010) and the average calving flux to be $1.3 \pm 0.4 \mathrm{Gt} \mathrm{yr}^{-1}$ (2007-2008). These numbers together with the grounding line flux mentioned earlier and a slightly positive net mass balance of $0.6 \mathrm{Gt} \mathrm{yr}^{-1}(2003-2008)$ result in a residual net basal melt of $3.9 \mathrm{Gt} \mathrm{yr}^{-1}$ or an average basal melt rate of $0.5 \pm 0.2 \mathrm{~m} \mathrm{yr}^{-1}$ (Rignot et al., 2013). Thus, basal melting comprises $\sim 75 \%$ of the total outgoing flux, with the residual $\sim 25 \%$ attributed to iceberg calving.

The continental shelf extends $\sim 100 \mathrm{~km}$ north of Nivlisen into the Lazarev Sea, and it is roughly $500 \mathrm{~m}$ deep (Arndt et al., 2013; Fig. 1a). Carbon dating of laminated sediments at several locations near the ice shelf suggests that the ice front retreated to its present position $\sim 11 \mathrm{kyr}$ ago (Gingele et al., 1997). North of Nivlisen lies Astrid Ridge (Fig. 1a), an undersea bathymetric feature extending from the Antarctic margin northward to $\sim 65^{\circ} \mathrm{S}$. Farther east lies Gunnerus Ridge (Fig. 1a), where circumpolar deep water is entrained into the Antarctic slope current. The circumpolar deep water is then cooled and modified to become warm deep water (Dong et al., 2016; Ryan et al., 2016) and flows westward along the continental slope before finally entraining into the Weddell Gyre. The ice shelf cavities in this region are separated from warm deep water by the Antarctic slope front, which is a pronounced transition zone over the narrow continental shelf between eastern shelf water and warm deep water. The slope front is mainly attributed to coastal downwelling caused by the prevailing easterly winds (Sverdrup, 1954; Thompson et al., 2018). The coastal dynamics that set the warm deep-water depth along the continental shelf break involves the balance between wind-driven Ekman overturning and counteracting eddy fluxes (Nøst et al., 2011; Thompson et al., 2014). These processes respond to changes in wind and buoyancy fluxes (Hattermann et al., 2014; Stewart and Thompson, 2016), including self-amplifying feedbacks of in- 
creased fresh-water input from increased basal melting (Hattermann, 2018).

The Southern Ocean, including the Weddell Sea, has warmed over recent decades (Gille, 2002; Schmidtko et al., 2014) with the changes driven primarily by anthropogenic climate warming (Swart et al., 2018). Sea ice cover has increased slightly since 1979 around Antarctica in general (De Santis et al., 2017); however extreme changes have occurred in recent years with record maxima 3 years in a row (2012 to 2014), followed by record minima in 2016 and 2017 (Shepherd et al., 2018; Stuecker et al., 2017; Turner et al., 2015). Sea ice fluctuations are strongly correlated with the dominant trends in Southern Hemisphere climate variability (Kwok et al., 2016; Kwok and Comiso, 2002), although further studies are needed to understand the drivers behind these fluctuations (Turner and Comiso, 2017). An increase in the seasonality of the easterly winds has been observed (Hazel and Stewart, 2019), and this may affect the formation and export of sea ice and the transport of surface waters and warm deep water to the continental shelf. All these pan-Antarctic observations may affect ocean water flow and consequent ice shelf thinning in Dronning Maud Land, but the consequences remain largely unknown.

\section{Data and methods}

We conducted three field campaigns on Nivlisen and adjacent ice rises during the Antarctic austral summers, from mid-November until the end of December 2016 to 2018, with logistic support from the Indian Maitri and Norwegian Troll Station (Fig. 1a). In December 2016, we installed stakes for the measurement of ice velocity and surface mass balance at 29 locations on Nivlisen and measured the ice thickness with an ApRES system (200-400 MHz), developed by the British Antarctic Survey (British Antarctic Survey, 2018; Nicholls et al., 2015; Fig. 1b): (1) 13 stakes were placed across the ice flow with a spacing of $10 \mathrm{~km}$ (profile A); (2) 10 stakes were placed along the ice flow towards a grounded ice rumple near the ice front with a spacing of 1 to $4 \mathrm{~km}$ (profile B); and (3) 4 stakes were placed along the ice flow towards the ice front with a spacing of $10 \mathrm{~km}$ (profile C). We also measured the ice shelf thickness and basal structure with a low-frequency $(5 \mathrm{MHz})$ radio echo sounder along these three profiles. After the initial measurements, we installed similar ApRES systems at two locations for hourly measurements of basal melting and strain rates over the winter, each powered by a $12 \mathrm{~V} 114 \mathrm{Ah}$ battery (Fig. 1b): (1) one $4 \mathrm{~km}$ from the ice shelf front, called the "seaward site" hereafter, and (2) the other $35 \mathrm{~km}$ from the ice shelf front, called the "landward site". In December 2017 and 2018, we revisited and remeasured all ApRES sites to get averaged annual values of basal melting and strain rates and retrieved the time series data from the two overwintering stations. Extensive crevass- ing prevented the three sites closest to the ice rumple (profile B, Fig. 1b) from being revisited in 2018 .

\subsection{Autonomous phase-sensitive radio echo sounder}

ApRES uses the frequency-modulated continuous wave (FMCW) technique (Rahman, 2016). The instrument transmits a signal sweeping from 200 to $400 \mathrm{MHz}$ over a period of $1 \mathrm{~s}$ to form a chirp (Nicholls et al., 2015). This is a lowpower consumption system, with the power to the transmitter antenna totalling $100 \mathrm{~mW}$. The averaged signal was amplified and de-ramped, a process where the received signal is mixed with a replica of the transmitted signal to extract differences in frequencies. The de-ramped signal was then filtered to amplify the higher frequencies preferentially, which enhanced weaker signals from more distant reflectors. Each sample consisted of 100 chirps, collected over a period of a few minutes. The data were digitized and stored on secure digital cards for further processing.

We processed the data following Brennan et al. (2014) and Nicholls et al. (2015). The data were Fourier transformed to give a complex signal amplitude as a function of delay time (or depth) assuming a constant propagation velocity of $168 \mathrm{~m} \mathrm{ss}^{-1}$. An amplitude cross correlation between the two returns, for a depth range within the firn layer (typically from 40 to $70 \mathrm{~m}$ ), provided a vertical shift that approximately accounted for snow accumulation between the visits. The displacement of the reflectors between the two visits was then plotted as a function of depth (Supplement Fig. S1a). To give the necessary depth resolution, the phase of the signals was used to calculate the displacements by cross-correlating $4 \mathrm{~m}$ segments of the first profile with the complex conjugate of the corresponding segment of the second. Under the assumption of a constant vertical strain rate between the bottom of the firn layer and just above the ice base, we fit a straight line to the layer displacements. The correction for snow accumulation between the two visits included the coarse correction mentioned above and the precise correction inherent in the phase processing. This effect, together with the effect of the non-linear (with depth) displacements due to firn compaction, was contained within the intercept at the vertical axis. Thus the basal melt was given by the deviation of the displacement of the basal reflection from the straight line fit (Supplement Fig. S1b). The error in the calculated strain was estimated using the quality of fit of the linear regression. The uncertainty in the melt rate was obtained by combining the uncertainty in the strain rate with the uncertainty in the change in the range to the basal reflector, deduced from the signal-to-noise ratios of the two basal reflections.

To calculate the hourly melt rate time series for the two overwintering sites (Fig. 1b), we tracked the basal reflector using phase-coherent processing. This allowed us to determine the speed of motion of the ice base with respect to the antenna, which we hereafter call the thinning rate. To remove the component of ice column vertical strain rate caused by 
tidal variations, we filtered the basal vertical speeds with a $36 \mathrm{~h}$ low-pass filter. We then removed an annual average vertical strain rate from the filtered basal motion, resulting in net basal melt rates. We assumed that, at periods longer than $36 \mathrm{~h}$, the variability in strain rate is small compared with the variability in basal melt rate.

\subsection{Low-frequency radar profiling}

We collected $\sim 180 \mathrm{~km}$ of continuous radio echo sounding profiles on Nivlisen to measure ice thickness and englacial and basal structure (profiles A, B, and C; Fig. 1b). We used a common-offset impulse radar system (Dowdeswell and Evans, 2004) based on the radar developed by Matsuoka et al. (2012) and processing steps following Lindbäck et al. (2014). We used half-wavelength dipole antennas with a $5 \mathrm{MHz}$ centre frequency, using a Kentech impulse transmitter with an average output power of $35 \mathrm{~W}$. The transmitter and receiver systems were mounted on two sleds and towed behind a snowmobile at a speed of $\sim 10 \mathrm{~km} \mathrm{~h}^{-1}$. We positioned the measurements using data from a code phase Global Positioning System (GPS) receiver mounted on the radar receiver box $20 \mathrm{~m}$ in front of the common mid-point of the antennas along the travelled trajectory of the snowmobile. We post-corrected the height using the Canadian precise pointprocessing service (CSRS-PPP; Natural Resources Canada, 2017) from a kinematic carrier phase dual-frequency GPS receiver mounted on the snowmobile. The radar measurements had an average trace spacing of $\sim 5 \mathrm{~m}$.

Several corrections and filters were applied to the radar data: (1) dewow and bandpass filters to remove unwanted frequency components in the data, (2) a depth-variable gain function, and (3) a normal move-out correction to correct for antenna separation, including adjusted travel times for the trigger delay. The basal returns were digitized semiautomatically with a cross-correlation picker at the first break of the bed reflection (Irving et al., 2007). We calculated ice thickness from the picked travel times of the bed return using a constant radio wave velocity of $168 \mathrm{~m} \mathrm{~s}^{-1}$ for ice. We added a correction term of $2 \mathrm{~m}$ to account for the faster propagation in the firn. The firn had a depth of $\sim 50 \mathrm{~m}$, derived from the ApRES internal reflectors (Supplement Fig. S1c). To show the depth of the base of the ice shelf in the water column, we calculated the ice draft from the ice thickness by subtracting the surface elevation, using an EIGEN-6C4 mean geoid height of $17 \mathrm{~m}$ above the ellipsoid (Förste et al., 2014). We estimated the error in ice thickness by standard analytical error propagation methods (Lapazaran et al., 2016; Taylor, 1996) outlined in Lindbäck et al. (2018). The estimation included the error in the radar acquisition and horizontal positioning error, where the radar acquisition errors comprised errors in radio wave velocity and two-way travel time. Velocity can vary spatially, depending mainly on density. Errors in two-way travel time were estimated to be the range resolution, which is the accuracy of the measurement of the distance between the antenna and the bed. The average radar system error was estimated to $13.3 \pm 1.2 \mathrm{~m}$. The surface and base of the ice shelf is relatively flat, giving very small vertical errors from horizontal positioning $(0.1 \pm 0.2 \mathrm{~m})$. The total error in ice thickness is presented together with the data in Sect. 4.

\subsection{Ice flow and surface mass balance from stakes}

Stake height over the surface was measured manually, and stake position was measured for 15 min using carrier phase dual-frequency GPS receivers at a $1 \mathrm{~s}$ logging interval. The stakes were revisited and measured in December 2017 and 2018. We processed the positions statically using CSRS-PPP (Natural Resources Canada, 2017). Snow density was measured at five locations on Nivlisen with an auger drill to a depth of $3 \mathrm{~m}$ and varied from 430 to $450 \mathrm{~kg} \mathrm{~m}^{-3}$. We used the average snow density of $440 \mathrm{~kg} \mathrm{~m}^{-3}$ and an ice density of $917 \mathrm{~kg} \mathrm{~m}^{-3}$ to calculate the surface mass balance in metres ice equivalent. Ice flow velocity and surface mass balance were compared with estimates from satellite data (Rignot et al., 2011) and regional atmospheric modelling (van de Berg et al., 2006).

\section{Results}

In 2017, averaged annual basal melt rates, at 29 ApRES sites on Nivlisen (Fig. 1b), ranged from $0.12 \pm 0.06$ to $3.94 \pm 0.04 \mathrm{~m} \mathrm{yr}^{-1}$ (Figs. 2a and 3), with a median value of $0.80 \mathrm{~m} \mathrm{yr}^{-1}$. The highest averaged annual basal melt rates were observed just upstream of an ice rumple at the ice front. The lowest melt rates were observed in the central and eastern parts of the ice shelf. In 2018, averaged annual basal melt rates at 26 sites ranged from $0.13 \pm 0.06$ to $1.48 \pm 0.01 \mathrm{~m} \mathrm{yr}^{-1}$ (Supplement Fig. S2). In 2018, the median melt rate was $0.72 \mathrm{~m} \mathrm{yr}^{-1}$. Basal melt rates were slightly lower in the second year at 18 sites and slightly higher for 8 sites. The measurements in 2018 excluded three sites closest to the ice rumple, which had the highest melt rates in 2017, since we were not able to revisit these sites because of many crevasses in the area. Errors in basal melt rates were on average $0.023 \mathrm{~m} \mathrm{yr}^{-1}$ in 2017 and $0.025 \mathrm{~m} \mathrm{yr}^{-1}$ in 2018.

Strain rates had a median annual value of $-4.7 \times 10^{-4} \mathrm{yr}^{-1}$ in 2017 and $-4.6 \times 10^{-4} \mathrm{yr}^{-1}$ in 2018 . The vertical strain rate contribution to the change of the average rate of thickness was $22 \%$ on average. The errors in strain were low, on average $6.2 \times 10^{-5} \mathrm{yr}^{-1}$ in 2017 and $7.1 \times 10^{-5} \mathrm{yr}^{-1}$ in 2018 . For most parts of the ice shelf the strain rates were negative, meaning that the ice was thinning by longitudinal stretching; however, close to the ice rumple mentioned earlier (profile B; Fig. 3) we observed a transition from negative to positive strain rates (from $-5.4 \times 10^{-4}$ to $2.2 \times 10^{-2} \mathrm{yr}^{-1}$ ), with increasing compressional thickening of the ice towards the ice rumple. Positive strain rates were also observed for five sites 

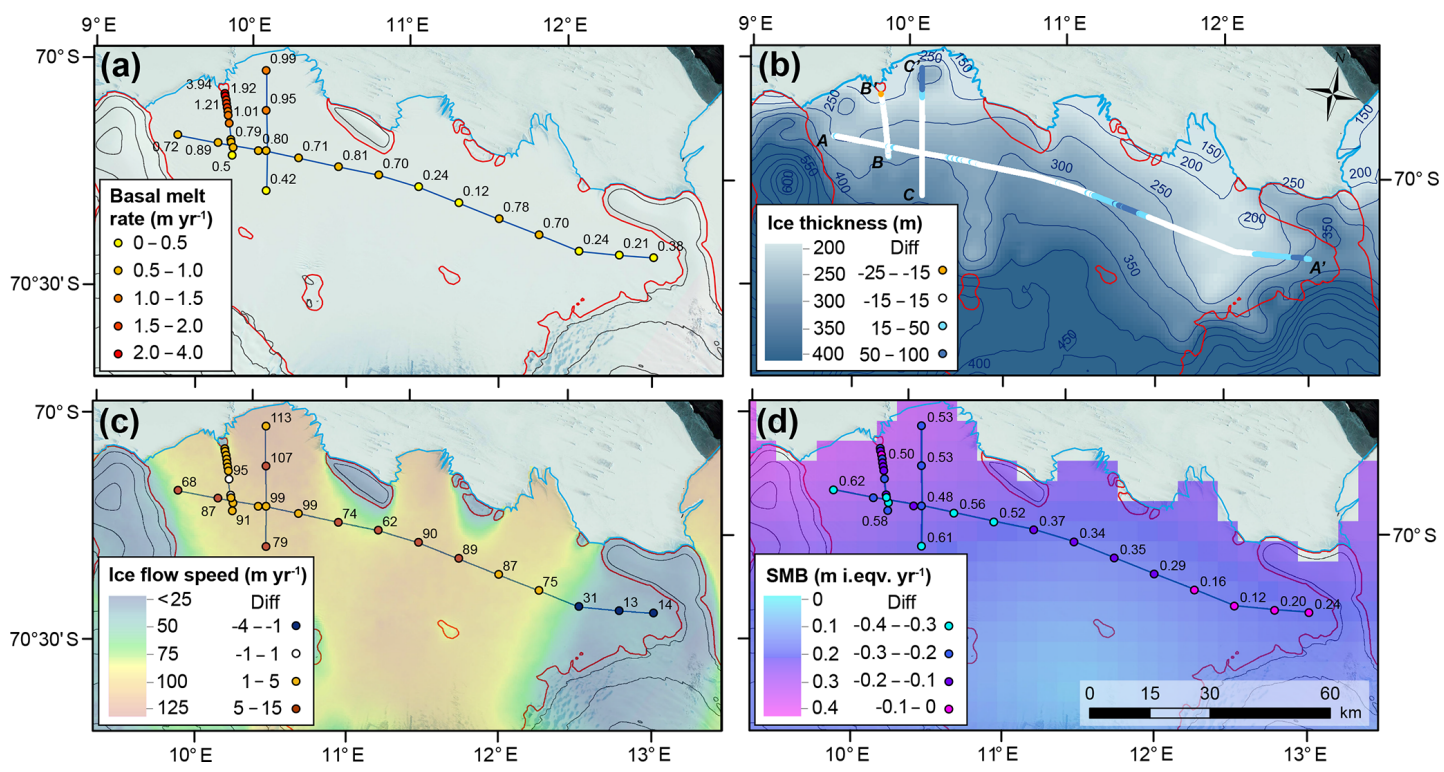

Figure 2. Comparison between in situ measured and satellite-derived or modelled values. (a) ApRES-derived averaged annual basal melt rates. See Supplement Fig. S2 for averaged annual basal melt rates for 2018, which is on average within $\pm 10 \%$ of the 2017 values. (b) Ice thickness from the Bedmap2 product (grid and contour lines; Fretwell et al., 2013) and difference to low-frequency radar profiles (satellite derived minus measured in point colour). (c) Ice flow speed from stakes (point numbers) and gridded satellite values (Rignot et al., 2011). Differences (satellite derived minus measured) are shown in point colour. (d) Surface mass balance (SMB) from stakes (point numbers) and gridded modelled values (van de Berg et al., 2006). Differences (modelled minus measured) are shown in point colour. Background image and contour lines are the same as in Fig. 1.

$5-10 \mathrm{~km}$ upstream of the larger ice rises in the central and in the eastern part of the ice shelf (profile A; Fig. 3), indicating a far-reaching buttressing effect (distance up to $\sim 30$ ice thicknesses from the ice rises).

The two overwintering ApRES systems were used to derive a time series of basal melt rates. The seaward overwintering site was located $4 \mathrm{~km}$ from the ice front and had an ice draft of $130 \mathrm{~m}$, as measured with low-frequency radar. It operated for 14 months (from 11 December 2016 to 4 February 2018) before the battery failed. At this site $36 \mathrm{~h}$ lowpass filtered basal melt rates varied from $\sim 0$ to $5.6 \mathrm{~m} \mathrm{yr}^{-1}$, where the highest melt rates occurred in summer (29 January 2017; Fig. 4a). The landward overwintering site was located $35 \mathrm{~km}$ from the ice front and had an ice draft of $280 \mathrm{~m}$. The data cover 22 months (from 4 January 2017 to 27 November 2018), excluding December 2017 when the instrument was used for measuring annual basal melt rates at other sites. At this site, $36 \mathrm{~h}$ low-pass filtered basal melt rates varied from $\sim 0$ to $2.0 \mathrm{~m} \mathrm{yr}^{-1}$, where the highest melt rates occurred in winter (12 June 2018; Fig. 5a).

Ice thickness, measured with low-frequency radar along profiles A, B, and C (Fig. 1b), varied from 160 to $330 \mathrm{~m}$ (Fig. 2b), with a median value of $260 \mathrm{~m}$. We observed the thinnest ice close to the ice front along profile C (Fig. 3), and the thickest ice was in the southernmost part of the ice shelf along the same profile. The total error in ice thickness along the profiles, including radar system and positioning errors, varied between 10.6 and $15.7 \mathrm{~m}$. The broad thickness pattern agrees with the gridded ice thickness from the Bedmap2 data suite (Fretwell et al., 2013), except close to the ice front in the western part (profile $\mathrm{C}$ ), where the thickness of Bedmap2 is clearly too high (Fig. 2b), possibly due to errors in the input data or the interpolation between them. Ice draft varied from 120 to $280 \mathrm{~m}$ with a median value of $220 \mathrm{~m}$ (Fig. 3). We observed no significant relation between basal melting and ice draft. Several locations with undulating englacial layers, basal channels, and crevasses were visible in the radar profiles (Fig. 3). Stake-measured ice flow speeds varied from 13 to $113 \mathrm{~m} \mathrm{yr}^{-1}$ in 2017, with an average value of $80 \mathrm{~m} \mathrm{yr}^{-1}$, agreeing with satellite estimates (Rignot et al., 2011; Fig. 2c). Surface mass balance values varied between 0.12 and $0.62 \mathrm{mi}$ i.e. $\mathrm{yr}^{-1}$ in 2017 with an average of 0.45 i.e. $\mathrm{yr}^{-1}$, higher than the modelled average estimates of $0.2 \mathrm{~m}^{2}$.e. $\mathrm{yr}^{-1}$ (van de Berg et al., 2006), but they had the same spatial pattern (Fig. 2d).

\section{Discussion}

In the following sections, we discuss the spatial and temporal variations in basal melting and compare our results with other studies from Antarctica. For each section, we also discuss strengths, limitations, and recommendations for future studies. 

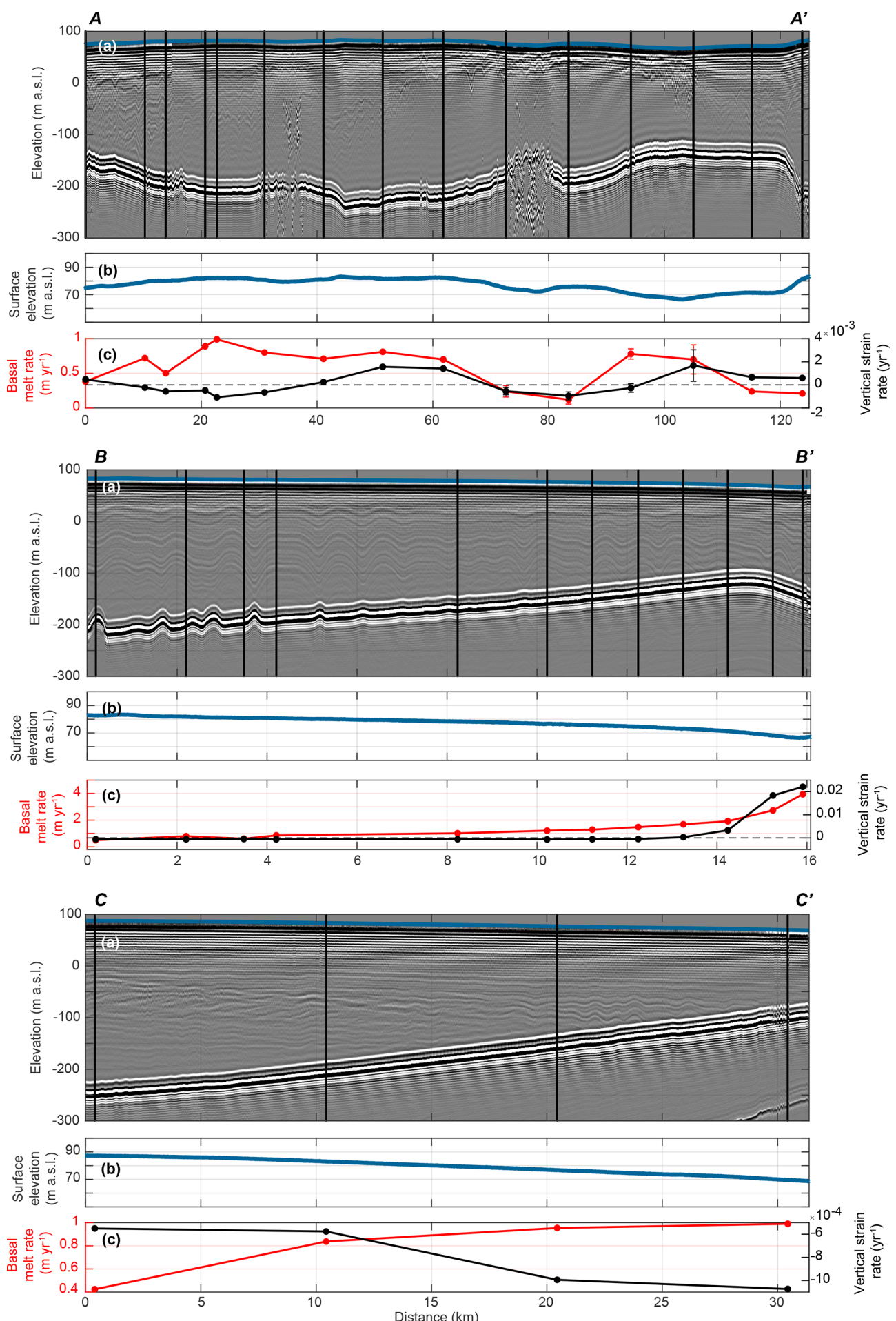

Figure 3. Profiles of low-frequency radar, ice surface elevation, basal melt, and strain (locations in Fig. $1 b$ ): $A-A^{\prime}$ across ice flow from west to east $(125 \mathrm{~km}), B-B^{\prime}$ along ice flow from south to north towards an ice rumple $(16 \mathrm{~km})$, and $C-C^{\prime}$ along ice flow from south to north towards the ice front $(32 \mathrm{~km})$. Sub-panels show (a) radar profiles with surface elevation (blue line), englacial stratigraphy, and basal elevation (grey-tone shading), and locations of ApRES measurements (black vertical lines), (b) surface elevation from carrier phase kinematic GPS measurements, and (c) annual basal melt rate (red) and vertical strain rates (black dashed line equal 0) for 2017. Note that the $x$ axis scales vary between the three profiles. 

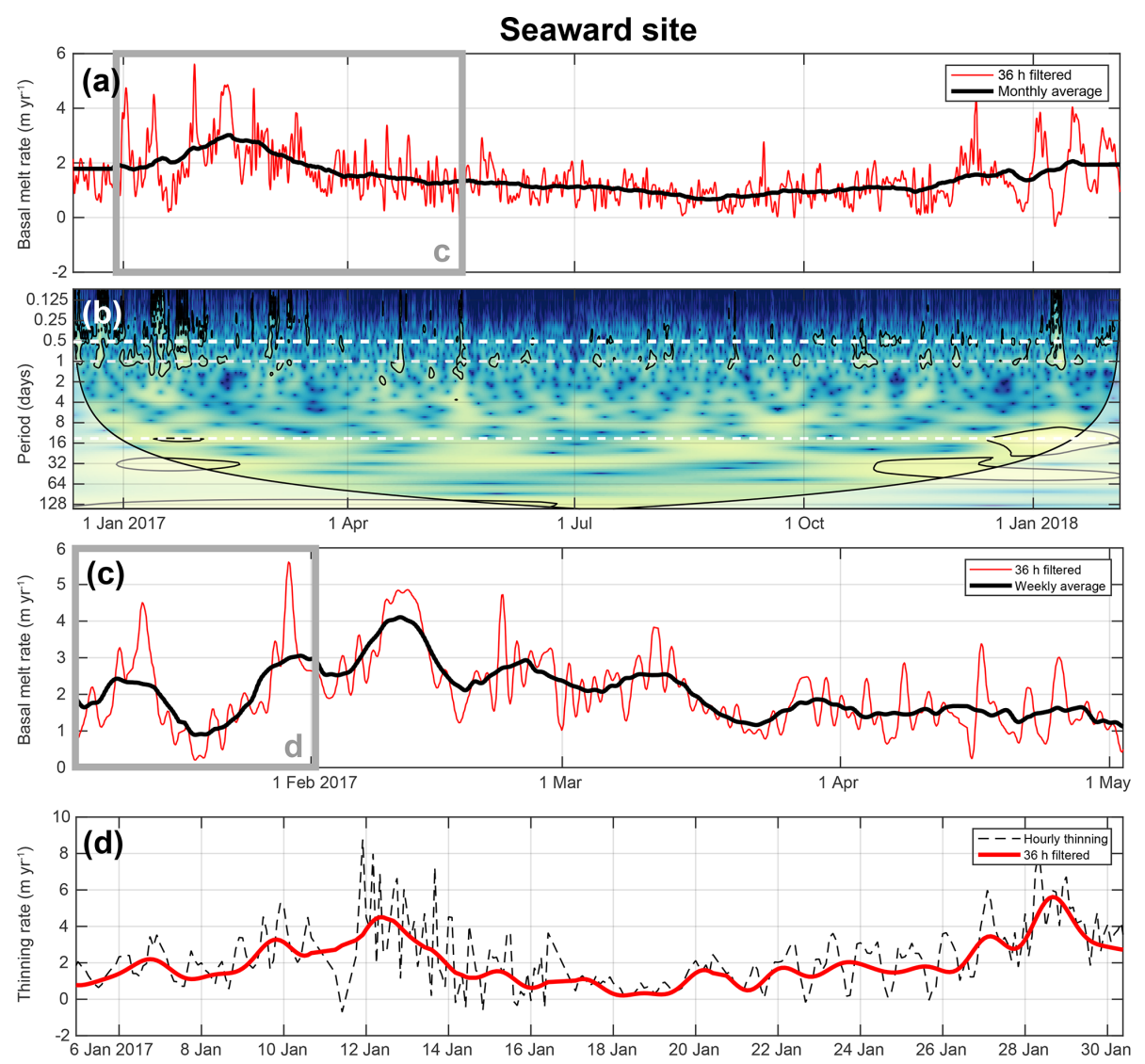

Figure 4. Basal melt and thinning rates for the seaward overwintering site, with variations on timescales of (a) months (11 December 20164 February 2018), (c) weeks (4 January-1 May 2017), and (d) days (1-31 January 2017). The dashed black line in (d) is the unfiltered raw data with a thickness change including strain rates. (b) Continuous wavelet transform of the normalized thinning to identify the dominant modes of variability at different timescales. The left axis is the Fourier period. The colour shading represents the thinning associated with fluctuations over the course of the year with a particular time period (yellow indicates high power, blue indicates low power). The black contours delimit significant modes of variance at $95 \%$ against red noise. Within the cone of influence, shown as a lighter shade in the right and left lower corners, edge effects may distort the image. Dashed white lines show the periods of major tidal constituents $\left(0.5 \mathrm{~d} \approx K_{1}, 1 \mathrm{~d}\right.$ $\approx M_{2} / S_{2}$, and $\left.14 \mathrm{~d} \approx M_{\mathrm{f}}\right)$

\subsection{Spatial variations in melting}

On Nivlisen, we observed the highest averaged annual basal melt rates $\left(3.9 \mathrm{~m} \mathrm{yr}^{-1}\right)$ close to a small $\left(4.2 \mathrm{~km}^{2}\right)$ ice rumple at the ice front (Figs. 2a and 3). Similar basal melt rates $\left(\sim 4 \mathrm{~m} \mathrm{yr}^{-1}\right)$ were inferred from satellite data near Bawden Ice Rise in the Antarctic Peninsula (Adusumilli et al., 2018). In modelling experiments, locally enhanced basal melt rates were caused by strong tidal currents in shallow regions (thin water column thickness) around the ice rise that increased the ice-ocean heat exchange (Mueller et al., 2012). At Nivlisen, we have no observations of ocean currents near the ice rumple, but the bathymetry must be shallow since the ice shelf grounds in this region. Ice shelf thinning could potentially increase the water column thickness, leading to a negative (stabilizing) feedback on the melting by reducing the ocean currents (Mueller et al., 2012, 2018; Padman et al., 2018). In terms of ice thickness change, the observed thinning from the basal melt is compensated by a positive vertical strain that implies compressional thickening towards the ice rumple (up to $4 \mathrm{~m} \mathrm{yr}^{-1}$ ). Thicker ice towards the ice rumple indicates a buttressing effect on the ice shelf (profile B; Fig. 3). We observed many crevasses in this region that made it, for safety reasons, difficult to revisit the three closest sites during the third field season (December 2018). Many ice shelves like Nivlisen are stabilized by pinning points at their ice fronts, which may be sensitive areas for future change. The effects of future increased basal melting at the Nivlisen ice rumple are uncertain, and modelling work may indicate whether ungrounding of the ice would potentially lead to substantial loss of buttressing (Borstad et al., 2013).

Estimates of basal melt rates for Dronning Maud Land ice shelves have mainly used satellite techniques, modelling, or limited spatial or temporal coverage of in situ radar observations (Berger et al., 2017; Langley et al., 2014b). Fimbulisen is situated $400 \mathrm{~km}$ west of Nivlisen (Fig. 1a) at the out- 

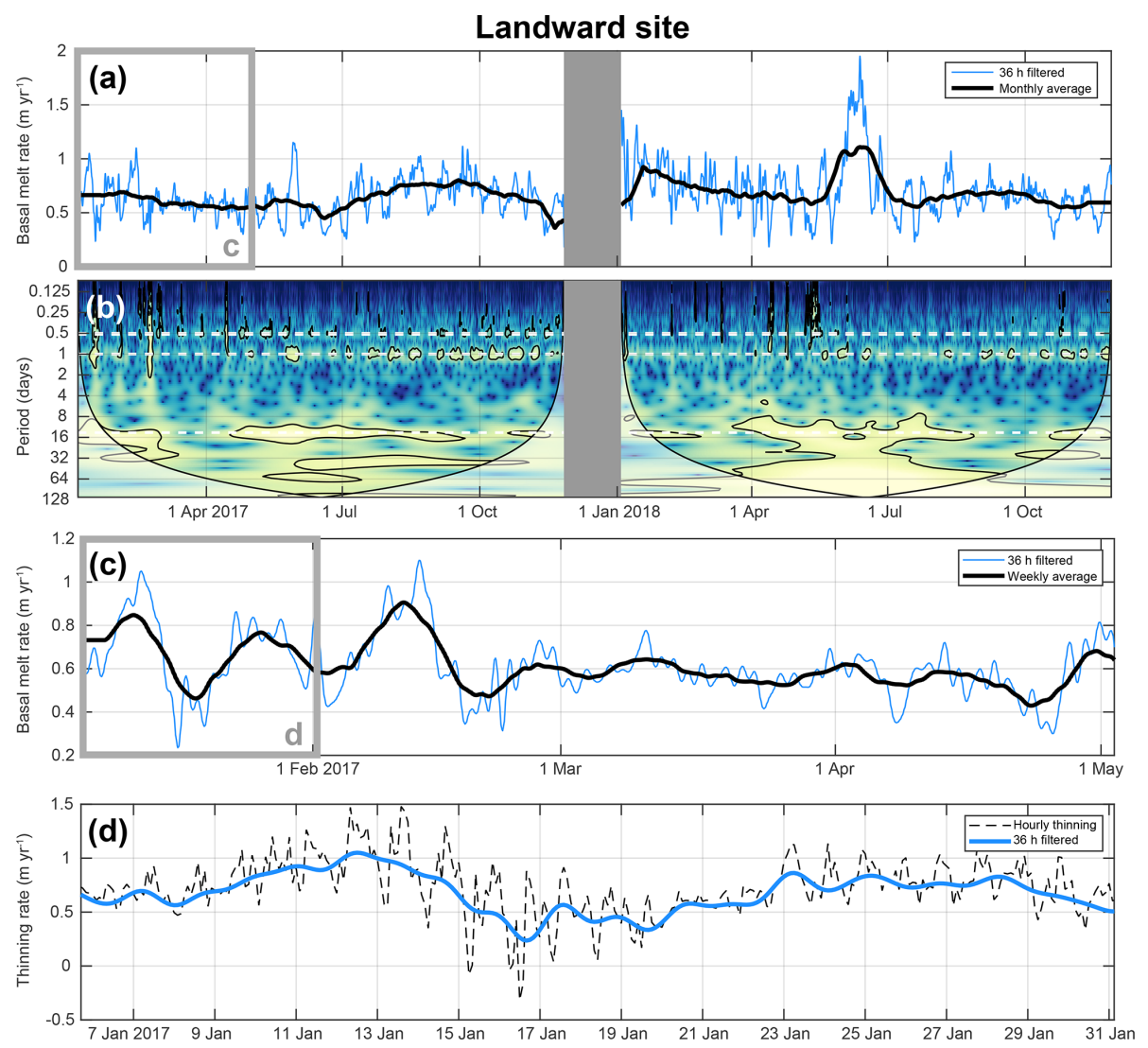

Figure 5. Basal melt and thinning rates for the landward overwintering site, with variations on timescales of (a) months (4 January 201727 November 2018), (c) weeks (4 January-1 May 2017), and (d) days (4-31 January 2017). (b) Continuous wavelet transform of the normalized thinning to identify the dominant modes of variability at different timescales. The grey box masks a time period with no data. See Fig. 4 caption for more information.

let of Jutulstraumen, one of the largest ice streams in Dronning Maud Land. Below the deep keel from Jutulstraumen (300-400 $\mathrm{m}$ ice draft), time-averaged basal melt rates of several metres per year were observed, whereas at the shallower parts of the ice shelf (200-300 $\mathrm{m}$ ice draft), lower melt rates were observed (Langley et al., 2014a). In addition, annual average basal melt rates were modelled to be near zero for large areas (Hattermann et al., 2014). Hattermann et al. (2014) hypothesized that basal melting (melt mode 1 , Sect. 1) occurred at the deepest parts of Fimbulisen (below ice drafts of $400 \mathrm{~m}$ ). The rising melt plume caused marine accretion at shallower depths closer to the ice front, which together with seasonal melting from summer-heated surface water (melt mode 3, Sect. 1), resulted in the low net basal melt rates. The seasonal marine-ice formation was inferred from an ice shelf cavity mooring (Hattermann et al., 2012). Nivlisen is in comparison relatively thin (Fig. 2b), and we have no melt observations from the thicker ice in the southern areas. Grounding line ice drafts (Fig. 1b) derived from Fretwell et al. (2013) and Mouginot et al. (2017) have an average value of $350 \mathrm{~m}$. The deepest part of the grounding line $(630 \pm 100 \mathrm{~m})$ is located at the outflow of Potsdam Glacier (Fig. 1b), where higher basal melt rates may occur. In addition, Nivlisen has three ice front sections, separated by ice rises and ice rumples, where the ocean can gain access to the inner parts of the ice shelf cavity. At Fimbulisen, Hattermann et al. $(2012,2014)$ found that a portion of the westward flowing coastal current was diverted under the ice shelf between two ice rises. Similar inflow pathways may also exist beneath the ice front sections of Nivlisen, explaining the variations of basal melt rates along profile A (Fig. 2a). At Fimbulisen, higher basal melt rates $\left(3 \mathrm{~m} \mathrm{yr}^{-1}\right)$ were also observed and modelled close to the ice front at shallow depths $(<200 \mathrm{~m}$; Hattermann et al., 2014; Langley et al., 2014b), which is consistent with our results.

In the low-frequency radar profiles, we observed several undulating ice base features (profiles A and B; Fig. 3), where the englacial layers warp downwards, which is likely an indication of basal channels or crevasses. The southernmost measurement in profile B is located at one of these downwarping features, where surface elevation is slightly lowered locally $(-0.5 \mathrm{~m})$. Higher basal melt rates were not observed here compared with the surrounding sites, although higher melt rates typically occur on the flanks of basal channels, rather than at their apex (Berger et al., 2017). The channel 
may have formed at an upstream ice rumple and been passively advected downstream (Fig. 2a). Basal channels are important features influencing the ice shelf stability, since they affect ice shelf cavity circulation and play a role in the exchange of heat and mass between the ocean and ice shelf (Gladish et al., 2012; McGrath et al., 2012; Millgate et al., 2013; Stanton et al., 2013). Basal channels are not restricted to rapidly melting ice shelves and have been observed elsewhere in Dronning Maud Land, at Fimbulisen (Langley et al., 2014a) and Roi Baudouin Ice Shelf (Fig. 1a; Berger et al., 2017). Detailed studies of these features together with basal melting are needed to understand their initiation, evolution, and role in the overall mass balance of ice shelves (Alley et al., 2016).

\subsection{Temporal variations in melting}

Basal melt rates at Nivlisen varied on a broad range of timescales (Figs. 4 and 5). At the seaward site, we observed a seasonal signal, where the monthly averaged basal melt rates were 2 to 3 times higher in summer than in winter (Figs. 4a and S3). At the landward site, we observed no seasonal pattern; however, some variability on monthly timescales was present (Figs. 5a and S3). We performed a continuous wavelet transform on the time series data from the two overwintering sites, based on the method and software package provided by Grinsted et al. (2004). The wavelet transform is used to study localized intermittent periodicities, in contrast to more traditional mathematical methods, such as a Fourier analysis, which assumes that the underlying process is stationary in time. We used a Morlet wavelet with $\omega_{0}=6$, which provides a good balance between time and frequency localization. The wavelet transform shows the normalized thinning rates at different scales to identify dominant periods of variability in time (Figs. $4 \mathrm{~b}$ and $5 \mathrm{~b}$ ). The statistical significance was assessed relative to the null hypothesis, modelled by a 1st-order autoregressive process. The wavelet transform has edge artefacts since it is not completely localized in time, as indicated by the cone of influence, masking out low-frequency signals at the beginning and end of the time series. The thinning variability at diurnal timescales, and to some extent semidiurnal timescales, varied at a period of approximately 2 weeks. This reflects the fortnightly spring neap tidal cycle at which the strength of the tidal currents varies because of the interference of different constituents, usually the semidiurnal lunar tide $\left(M_{2}\right)$ and the semidiurnal solar tide $\left(S_{2}\right)$ in this area (plotted as white dashed lines in Figs. $4 \mathrm{~b}$ and 5b). Stronger tidal currents increase the heat exchange at the ice-ocean interface and may hence cause more rapid melt. At periods shorter than $36 \mathrm{~h}$, however, we cannot differentiate the strain signal from the melt signal. We also see some evidence of a slower variability in the data centred on 2-4d (Figs. 4d and 5d), which may be a result of mesoscale activity passing by the site (eddies or internal waves), which then show up in the melt rate. This is to some

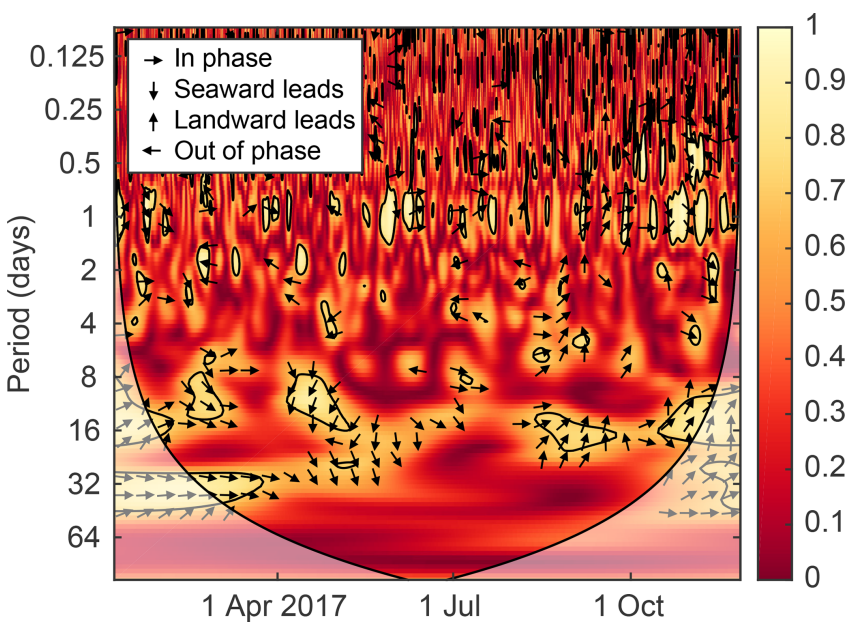

Figure 6. Wavelet coherence between overlapping time periods at the seaward and landward sites (4 January-27 November 2017) showing times where the basal melt rates have common power. The phase relationship is shown as arrows. At longer periods (8$30 \mathrm{~d}$ ) in summer to autumn (January-April) the signals are in phase, whereas in winter (April-June) the melt at the seaward site leads the signal. In late winter (September) the phase shifts to the landward site leading the signal. Within the cone of influence, shown as a lighter shade, edge effects become important.

extent supported by Fourier analysis of the normalized $36 \mathrm{~h}$ filtered basal melt rates, which show peaks in power spectral density at $2-4 \mathrm{~d}$, mostly visible at the seaward site (Supplement Fig. S4).

At the landward site, we observed no increased melting in summer, but we observed one melt peak in winter (12 June 2018; Fig. 5a). The melt event may have been caused by pulses of modified warm deep water reaching the base of the ice shelf as described by Hattermann et al. (2012), but it could also relate to other mesoscale activities within the cavity. In any case, the isolated event and the generally low basal melt rates suggest that warm deep water had limited access to the base of Nivlisen during 2017 and 2018. This observation is consistent with earlier studies, showing that ice shelf cavities in this region are mainly filled with cold and fresh eastern shelf water (Nicholls et al., 2006; Thompson et al., 2018). Many factors control the extent to which warm deep water can access the ice shelf cavities in Dronning Maud Land, such as the stability of the Antarctic slope front, local circulation, and bathymetry, and this has to be studied in more detail.

We studied the coherency between the two overwintering melt sites in a wavelet coherence (Grinsted et al., 2004) for the overlapping time periods in 2017 (Fig. 6). The wavelet coherence analysis finds significant coherence even if the common power is low, and it shows significant confidence levels against red-noise backgrounds. Locally phase-locked behaviour can also be revealed; at weekly-to-monthly periods (7-30 d) in summer to autumn (January-April 2017) the 

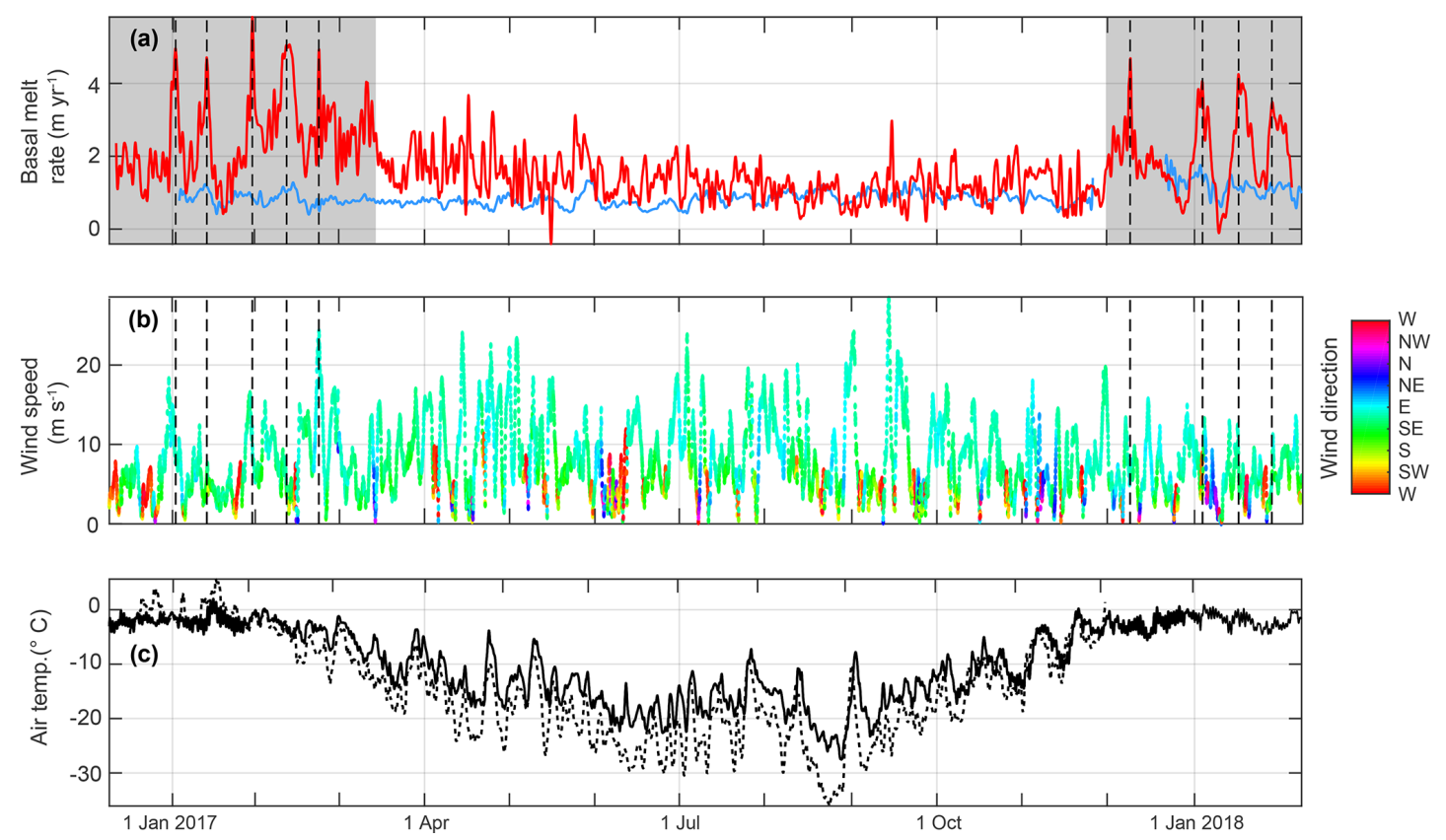

Figure 7. Basal melt rates compared with atmospheric forcing and sea ice cover. (a) Values of $36 \mathrm{~h}$ low-pass filtered basal melt rates at the seaward site (red) and landward site (blue). The shaded grey area represents the time period in satellite data when there is open water in front of the ice shelf (Supplement Fig. S6). ERA5 reanalysis surface data of (b) wind speed and direction and (c) $2 \mathrm{~m}$ air temperature, where the dashed black line is data from a nearby weather station (Fig. 1b). Vertical dashed lines show where time lags were calculated between basal melt and wind peaks.

basal melt rates were in phase, whereas in winter (AprilJune) the melting at the seaward site led the increased signal, preceding the melt at the landward site. In late winter (September), the phase shifted to the landward site leading the melt. At Fimbulisen, the inflow of summer-warmed Antarctic surface water was observed at moorings close to the ice shelf front with a clear seasonal signal in water temperatures and salinity (Hattermann et al., 2012). Hattermann et al. (2014) suggested that Antarctic surface water can reside for several months below the ice shelf cavity, after initially being subducted beneath the ice front, potentially affecting basal melting deep inside the cavity. The observed melt rate pattern beneath Nivlisen may be an indication of similar movement of water masses below the ice shelf, and further observations and modelling are needed to study these processes, currently being hampered by the lack of knowledge of bathymetry beneath the ice shelf.

We compared the basal melt rates with atmospheric reanalysis data from the ERA5 data set of wind speed, wind direction, air temperature, and sea ice cover (Fig. 7) produced by the European Centre for Medium-Range Weather Forecasts (Copernicus Climate Change Service (C3S), 2017) at a grid point $10 \mathrm{~km}$ north of the ice shelf front (Fig. 1b). ERA5 wind speeds at Nivlisen varied on daily timescales ranging from 0 to $28 \mathrm{~m} \mathrm{~s}^{-1}$. Winds generally blew from the east (Fig. 7b), corresponding to the pressure gradients imposed by the cyclonic system that dominates the Weddell
Sea. As wind forcing can play an important role in the downwelling and transportation of summer-warmed Antarctic surface water into the ice shelf cavity (Zhou et al., 2014), we calculated the coherence between the normalized basal melt rates at the seaward site and wind speeds during time periods when there was open water in front of the ice shelf (grey area in Fig. 7a). The statistical significance level was estimated using a Monte Carlo simulation with a Fourier transform method, where a large set of surrogate data set pairs were generated using phase randomization (Schreiber and Schmitz, 2000). We found a significant coherence between basal melt rates and wind speeds ( $r=0.35, p<0.01$; Fig. 8 ). We found no such coherence in winter. The variability in winter may be due to the transport being mainly dominated by eddies, shed by instabilities in the along-slope current. We also compared individual melt peaks in summer with higher wind events (dashed vertical lines in Fig. 7). The melt peaks have a time lag of $\sim 0$ to $3 \mathrm{~d}$ after a wind event. Air temperatures at $2 \mathrm{~m}$ varied mostly on seasonal timescales, with temperatures between 0 and $-10^{\circ} \mathrm{C}$ in summer, when we observe the highest basal melting, and down to $-28^{\circ} \mathrm{C}$ in winter (Fig. 7c). The temperature variability in the reanalysis data on shorter timescales agreed with our weather station on Leningradkollen (190 ma.s.l.); however, the seasonal temperature signal had a lower amplitude than at the weather station, which measured temperatures down to $-38^{\circ} \mathrm{C}$. When air temperatures were high and basal melt rates increased 


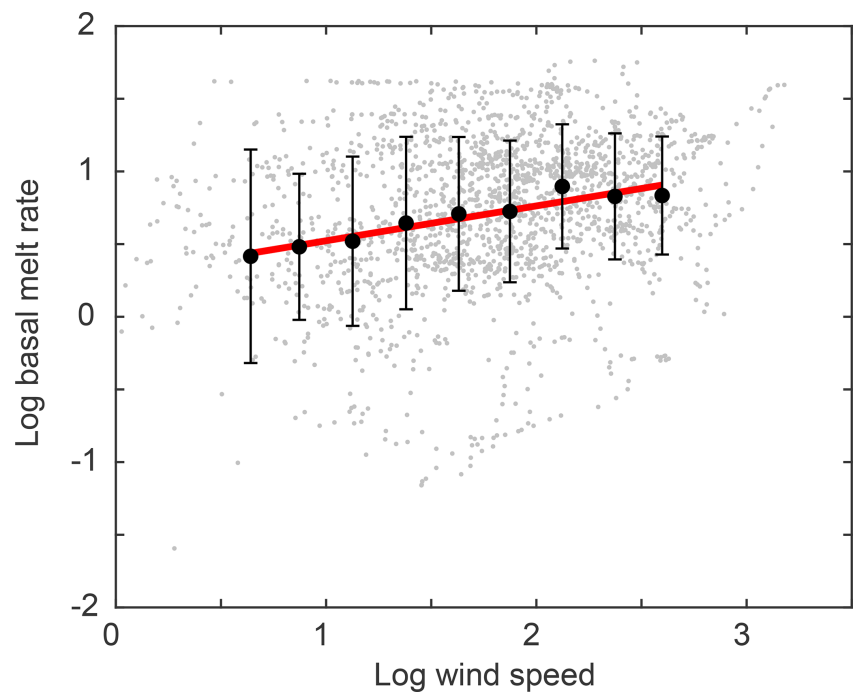

Figure 8. Scatter plot with the normalized basal melt rates at the seaward site and wind speeds for the time period when there was open water in front of the ice shelf (grey area in Fig. 7a). Black points show the average basal melt rate calculated for each wind speed bin in intervals of 0.25 . The red line shows the linear regression.

in early summer at the seaward site (December 2016 and 2017), we observed open water close to Nivlisen, which is the time when solar radiation may warm the surface waters (Fig. 7). Sea ice is widespread in front of the ice shelf during winter and then breaks up during summer typically starting from the west and progressing to the more sheltered eastern side (Supplement Fig. S5). The general pattern of summer retreat is interrupted by irregular periods of some sea ice regrowth (e.g. early February 2017 and 2018; Fig. S5). Similar seasonally higher basal melt rates (up to $\sim 5 \mathrm{~m} \mathrm{yr}^{-1}$ ) were observed at Ross Ice Shelf in West Antarctica, where solar-heated surface water in a polynya near the ice front was linked to the higher melt rates; however, they did not find any link to downwelling-favourable winds, but rather a link was found for density gradients caused by seasonal brine release in the polynya (Stewart et al., 2019).

In summary, the basal melt rates varied on seasonal, monthly, and daily timescales related to the tidal cycles and mesoscale activities in the ice shelf cavity. We hypothesize that summer-warmed Antarctic surface water was pushed by wind under the front of the ice shelf. Reduced sea ice cover and higher wind speeds may increase melting from surface waters, while weaker winds and/or changes in the surface buoyancy forcing may increase exposure of the ice shelf cavities to warm deep water. Surface winds are projected to intensify over the next century with increased greenhouse gas emissions (Greene et al., 2017), and extreme changes in sea ice extent have occurred in recent years (Shepherd et al., 2018). Warming of the surface water is projected to increase ice shelf melting along Dronning Maud Land in fu- ture climate scenarios (Kusahara and Hasumi, 2013), and recent studies suggest that non-linear feedbacks may facilitate an irreversible transition into a state of higher melting in the Weddell Sea (Hattermann, 2018; Hellmer et al., 2017). Increases in basal melting will tend to thin the ice shelves and reduce the buttressing on the inland ice sheet. It remains to be understood to what extent increased summer warmth-driven melting, intensified in the vicinity of pinning points, may affect the ice flow dynamics and ice shelf stability.

\section{Conclusions}

We present a 2-year record of basal melting at Nivlisen in Dronning Maud Land, East Antarctica, at a high spatial and temporal resolution using in situ phase-sensitive radar measurements. Averaged annual basal melt rates are in general moderate $\left(0.8 \mathrm{~m} \mathrm{yr}^{-1}\right)$, but relatively high melt rates were observed close to a grounded feature near the ice shelf front. Hourly measurements also reveal a seasonal melt pattern close to the ice shelf front, where the highest basal melt rates occurred in summer $\left(5.6 \mathrm{~m} \mathrm{yr}^{-1}\right)$. Comparing the seasonality in basal melting with forcing from atmospheric reanalysis data, we found that the variability in the basal melt is likely caused by summer-warmed surface water pushed by wind into the ice shelf cavity. Farther into the ice shelf cavity, we observe a different melt regime, with significantly lower basal melt rates and a clearer tidal signal. We conclude that warm deep-ocean water has a limited effect on the basal melting of Nivlisen, likely because the present configuration of the Antarctic slope front, which separates the deeper water from the continent, protects the ice shelf from those warmer water masses. Our study highlights that, although many of the ice shelves in East Antarctica have generally low basal melt rates, their seaward sections have temporally higher basal melt rates due to the influence of summerwarmed surface waters. The frontal areas are stabilized by pinning points, and these areas could potentially be sensitive to future change if the basal rates would increase. We demonstrate the use of and need for continuous in situ monitoring of Antarctic ice shelves to resolve variability in basal melting that is not captured in satellite data. Long-term, highresolution time series data are crucial to understanding the complex mechanisms involved in ice shelf-ocean interactions.

Data availability. The compiled data sets of basal melt rates, strain rates, ice flow velocity, surface mass balance, and ice thickness from low-frequency radar profiling are available at the Norwegian Polar Institute (2019; https://data.npolar.no/; https://www.npolar.no/ prosjekter/madice, last access: 1 September 2019).

Supplement. The supplement related to this article is available online at: https://doi.org/10.5194/tc-13-2579-2019-supplement. 
Author contributions. KL led the overall data analysis and interpretations and prepared the paper with contributions from all coauthors. KL, GM, and BP collected the ApRES, ice flow, and surface mass balance data. KWN was responsible for the ApRES system setup. KM was responsible for the low-frequency radar system and collected the data. TH contributed to the discussion section. MT and $\mathrm{KM}$ were the project leaders.

Competing interests. Kenichi Matsuoka is a member of the editorial board of the journal.

Acknowledgements. This work was part of the MADICE (Mass balance, dynamics, and climate of the central Dronning Maud Land coast, East Antarctica) project, funded by the Research Council of Norway and the Ministry of Earth Sciences, India. We would like to thank the NCPOR and NPI logistic heads and personnel who helped us in the field. We also thank Chris Borstad for estimating flow lines to the ice rumple, Harvey Goodwin for assessing field safety, Vikram Goel for helping collect data in the field, and Robert Graham for providing the ERA5 data. Figures 1 and 2 were prepared using Quantarctica (https://quantarctica.npolar.no/, last access: 1 September 2019). For the REMA data set we acknowledge the following: DEMs were provided by the Byrd Polar and Climate Research Center and the Polar Geospatial Center under NSFOPP award nos. 1543501, 1810976, 1542736, 1559691, 1043681, 1541332, 0753663, 1548562, and 1238993 and NASA award no. NNX10AN61G. Computer time was provided through a Blue Waters Innovation Initiative. DEMs were produced using data from DigitalGlobe, Inc. We thank the two anonymous reviewers and the editor Nanna Bjørnholt Karlsson for their valuable suggestions and comments.

Financial support. This research has been supported by the Research Council of Norway (grant no. 248780) and the Ministry of Earth Sciences, India (grant no. MoES/Indo-Nor/PS-3/2015).

Review statement. This paper was edited by Nanna Bjørnholt Karlsson and reviewed by two anonymous referees.

\section{References}

Adusumilli, S., Fricker, H. A., Siegfried, M. R., Padman, L., Paolo, F. S., and Ligtenberg, S. R. M.: Variable Basal Melt Rates of Antarctic Peninsula Ice Shelves, 1994-2016, Geophys. Res. Lett., 45, 4086-4095, https://doi.org/10.1002/2017GL076652, 2018.

Alley, K. E., Scambos, T. A., Siegfried, M. R., and Fricker, H. A.: Impacts of warm water on Antarctic ice shelf stability through basal channel formation, Nat. Geosci., 9, 290-293, https://doi.org/10.1038/NGEO2675, 2016.

Anschütz, H., Eisen, O., Oerter, H., Steinhage, D., and Scheinert, M.: Investigating small-scale variations of the recent accumulation rate in coastal Dronning
Maud Land, East Antarctica, Ann. Glaciol., 46, 14-21, https://doi.org/10.3189/172756407782871756, 2007.

Arndt, J. E., Schenke, H. W., Jakobsson, M., Nitsche, F. O., Buys, G., Goleby, B., Rebesco, M., Bohoyo, F., Hong, J., Black, J., Greku, R., Udintsev, G., Barrios, F., Reynoso-Peralta, W., Taisei, M., and Wigley, R.: The International Bathymetric Chart of the Southern Ocean (IBCSO) Version 1.0 - A new bathymetric compilation covering circum-Antarctic waters, Geophys. Res. Lett., 40, 3111-3117, https://doi.org/10.1002/grl.50413, 2013.

Bamber, J. L., Westaway, R. M., Marzeion, B., and Wouters, B.: The land ice contribution to sea level during the satellite era, Environ. Res. Lett., 13, 063008, https://doi.org/10.1088/17489326/aac2f0, 2018.

Berger, S., Drews, R., Helm, V., Sun, S., and Pattyn, F.: Detecting high spatial variability of ice shelf basal mass balance, Roi Baudouin Ice Shelf, Antarctica, The Cryosphere, 11, 2675-2690, https://doi.org/10.5194/tc-11-2675-2017, 2017.

Bindschadler, R., Vornberger, P., Fleming, A., Fox, A., Mullins, J., Binnie, D., Paulsen, S. J., Granneman, B., and Gorodetzky, D.: Remote Sensing of Environment The Landsat Image Mosaic of Antarctica, Remote Sens. Environ., 112, 4214-4226, https://doi.org/10.1016/j.rse.2008.07.006, 2008.

Borstad, C. P., Rignot, E., Mouginot, J., and Schodlok, M. P.: Creep deformation and buttressing capacity of damaged ice shelves: theory and application to Larsen C ice shelf, The Cryosphere, 7, 1931-1947, https://doi.org/10.5194/tc-7-1931-2013, 2013.

Brennan, P. V, Lok, L. B., Nicholls, K., and Corr, H.: Phasesensitive FMCW radar system for high-precision Antarctic ice shelf profile monitoring, IET Radar Sonar Navig., 8, 776-786, https://doi.org/10.1049/iet-rsn.2013.0053, 2014.

British Antarctic Survey: Instrument: Phase-sensitive radar (ApRES), available at: https://www.bas.ac.uk/polar-operations/ sites-and-facilities/facility/phase-sensitive-radar-apres/, last access: 13 November 2018.

Copernicus Climate Change Service (C3S): ERA5: Fifth generation of ECMWF atmospheric reanalyses of the global climate, Copernicus Clim. Chang. Serv. Clim. Data Store, available at: https: //www.ecmwf.int/en/forecasts/datasets/reanalysis-datasets/era5 (last access: 1 November 2018), 2017.

Corr, H. F. J., Jenkins, A., Nicholls, K. W., and Doake, C. S. M.: Precise measurement of changes in ice-shelf thickness by phasesensitive radar to determine basal melt rates, Geophys. Res. Lett., 29, 1232, https://doi.org/10.1029/2001GL014618, 2002.

Darelius, E. and Sallée, J. B.: Seasonal Outflow of Ice Shelf Water Across the Front of the Filchner Ice Shelf, Weddell Sea, Antarctica, Geophys. Res. Lett., 45, 3577-3585, https://doi.org/10.1002/2017GL076320, 2017.

Davis, P. E. D., Jenkins, A., Nicholls, K. W., Brennan, P. V., Povl Abrahamsen, E., Heywood, K. J., Dutrieux, P., Cho, K.-H., Kim, T.-W., and Povl Abrahamsen, E.: Variability in Basal Melting Beneath Pine Island Ice Shelf on Weekly to Monthly Timescales, J. Geophys. Res.-Oceans, 123, 8655-8669, https://doi.org/10.1029/2018JC014464, 2018.

Depoorter, M. A., Bamber, J. L., Griggs, J. A., Lenaerts, J. T. M., Ligtenberg, S. R. M., van Den Broeke, M. R., and Moholdt, G.: Calving fluxes and basal melt rates of Antarctic ice shelves, Nature, 502, 89-92, https://doi.org/10.1038/nature12567, 2013.

De Santis, A., Maier, E., Gomez, R., and Gonzalez, I.: Antarctica, 1979-2016 sea ice extent: total versus re- 
gional trends, anomalies, and correlation with climatological variables, Int. J. Remote Sens., 38, 7566-7584, https://doi.org/10.1080/01431161.2017.1363440, 2017.

Dong, J., Speer, K., and Jullion, L.: The Antarctic Slope Current near 30 deg E, J. Geophys. Res.-Oceans, 121, 1051-1062, https://doi.org/10.1002/2015JC011099, 2016.

Dowdeswell, J. A. and Evans, S.: Investigations of the form and flow of ice sheets and glaciers using radio-echo sounding, Reports Prog. Phys., 67, 1821-1861, https://doi.org/10.1088/00344885/67/10/R03, 2004.

Dupont, T. K. and Alley, R. B.: Assessment of the importance of ice-shelf buttressing to ice-sheet flow, Geophys. Res. Lett., 32, 1-4, https://doi.org/10.1029/2004GL022024, 2005.

Favier, L., Gagliardini, O., Durand, G., and Zwinger, T.: A threedimensional full Stokes model of the grounding line dynamics: effect of a pinning point beneath the ice shelf, The Cryosphere, 6, 101-112, https://doi.org/10.5194/tc-6-101-2012, 2012.

Förste, C., Bruinsma, S. L., Abrikosov, O., Lemoine, J.-M., Marty, J. C., Flechtner, F., Balmino, G., Barthelmes, F., and Biancale, R.: EIGEN-6C4 The latest combined global gravity field model including GOCE data up to degree and order 2190 of GFZ Potsdam and GRGS Toulouse, GFZ Data Serv., https://doi.org/10.5880/icgem.2015.1, 2014.

Fretwell, P., Pritchard, H. D., Vaughan, D. G., Bamber, J. L., Barrand, N. E., Bell, R., Bianchi, C., Bingham, R. G., Blankenship, D. D., Casassa, G., Catania, G., Callens, D., Conway, H., Cook, A. J., Corr, H. F. J., Damaske, D., Damm, V., Ferraccioli, F., Forsberg, R., Fujita, S., Gim, Y., Gogineni, P., Griggs, J. A., Hindmarsh, R. C. A., Holmlund, P., Holt, J. W., Jacobel, R. W., Jenkins, A., Jokat, W., Jordan, T., King, E. C., Kohler, J., Krabill, W., Riger-Kusk, M., Langley, K. A., Leitchenkov, G., Leuschen, C., Luyendyk, B. P., Matsuoka, K., Mouginot, J., Nitsche, F. O., Nogi, Y., Nost, O. A., Popov, S. V., Rignot, E., Rippin, D. M., Rivera, A., Roberts, J., Ross, N., Siegert, M. J., Smith, A. M., Steinhage, D., Studinger, M., Sun, B., Tinto, B. K., Welch, B. C., Wilson, D., Young, D. A., Xiangbin, C., and Zirizzotti, A.: Bedmap2: improved ice bed, surface and thickness datasets for Antarctica, The Cryosphere, 7, 375-393, https://doi.org/10.5194/tc-7-375-2013, 2013.

Gille, S. T.: Warming of the Southern Ocean Since the 1950s, Science, 295, 1275-1277, https://doi.org/10.1126/science.1065863, 2002.

Gingele, F. X., Kuhn, G., Maus, B., Melles, M., and Schöne, T.: Holocene ice retreat from the Lazarev Sea shelf, East Antarctica, Cont. Shelf Res., 17, 137-163, https://doi.org/10.1016/S02784343(96)00026-X, 1997.

Gladish, C. V., Holland, D. M., Holland, P. R., and Price, S. F.: Iceshelf basal channels in a coupled ice/ocean model, J. Glaciol., 58, 1227-1244, https://doi.org/10.3189/2012JoG12J003, 2012.

Gladstone, R. M., Lee, V., Rougier, J., Payne, A. J., Hellmer, H., Le, A., Shepherd, A., Edwards, T. L., Gregory, J., and Cornford, S. L.: Calibrated prediction of Pine Island Glacier retreat during the $21 \mathrm{st}$ and $22 \mathrm{nd}$ centuries with a coupled flowline model, Earth Planet. Sc. Lett., 333-334, 191-199, https://doi.org/10.1016/j.epsl.2012.04.022, 2012.

Goel, V., Matsuoka, K., Berger, C. D., Lee, I., Dall, J., and Forsberg, R.: Characteristics of Ice Rises and Ice Rumples in Dronning Maud Land, Antarctica, J. Glaciol., in review, 2019.
Greene, C. A., Blankenship, D. D., Gwyther, D. E., Silvano, A., and van Wijk, E.: Wind causes Totten Ice Shelf melt and acceleration, Sci. Adv., 3, 1-5, https://doi.org/10.1126/sciadv.1701681, 2017.

Grinsted, A., Moore, J. C., and Jevrejeva, S.: Application of the cross wavelet transform and wavelet coherence to geophysical time series, Nonlin. Processes Geophys., 11, 561-566, https://doi.org/10.5194/npg-11-561-2004, 2004.

Hattermann, T.: Antarctic Thermocline Dynamics along a Narrow Shelf with Easterly Winds, J. Phys. Oceanogr., 48, 2419-2442, https://doi.org/10.1175/JPO-D-18-0064.1, 2018.

Hattermann, T., Nøst, O. A., Lilly, J. M., and Smedsrud, L. H.: Two years of oceanic observations below the Fimbul Ice Shelf, Antarctica, Geophys. Res. Lett., 39, L12605, https://doi.org/10.1029/2012GL051012, 2012.

Hattermann, T., Smedsrud, L. H., Nøst, O. A., Lilly, J. M., and Galton-Fenzi, B. K.: Eddy-resolving simulations of the Fimbul Ice Shelf cavity circulation: Basal melting and exchange with open ocean, Ocean Model., 82, 28-44, https://doi.org/10.1016/j.ocemod.2014.07.004, 2014.

Hazel, J. E. and Stewart, A. L.: Are the Near-Antarctic Easterly Winds Weakening in Response to Enhancement of the Southern Annular Mode?, J. Climate, 32, 1895-1918, https://doi.org/10.1175/jcli-d-18-0402.1, 2019.

Hellmer, H., Kauker, F., Timmermann, R., and Hattermann, T.: The Fate of the Southern Weddell Sea Continental Shelf in a Warming Climate, J. Climate, 30, 4337-4350, https://doi.org/10.1175/JCLI-D-16-0420.1, 2017.

Heywood, K. J., Locarnini, R. A., Frew, R. D., Dennis, P. F., and King, B. A.: Transport and water masses of the Antarctic slope front system in the eastern Weddell Sea, Ocean, Ice, Atmos. Interact. Antarct. Cont. Margin, 24, 203-214, https://doi.org/10.1029/ar075p0203, 1998.

Hogg, A. E. and Gudmundsson, G. H.: Impacts of the LarsenC Ice Shelf calving event, Nat. Clim. Change, 7, 540-542, https://doi.org/10.1038/nclimate3359, 2017.

Holland, P. R., Brisbourne, A., Corr, H. F. J., McGrath, D., Purdon, K., Paden, J., Fricker, H. A., Paolo, F. S., and Fleming, A. H.: Oceanic and atmospheric forcing of Larsen C Ice-Shelf thinning, The Cryosphere, 9, 1005-1024, https://doi.org/10.5194/tc9-1005-2015, 2015.

Horwath, M., Dietrich, R., Baessler, M., Nixdorf, U., Steinhage, D., Fritzsche, D., Damm, V., and Reitmayr, G.: Nivlisen, an Antarctic ice shelf in Dronning Maud Land: geodetic - glaciological results from a combined analysis of ice thickness, ice surface height and ice-flow observations, J. Glaciol., 52, 17-30, https://doi.org/10.3189/172756506781828953, 2006.

Howat, I. M., Porter, C., Smith, B. E., Noh, M.-J., and Morin, P.: The Reference Elevation Model of Antarctica, The Cryosphere, 13, 665-674, https://doi.org/10.5194/tc-13-665-2019, 2019.

IMBIE Team: Mass balance of the Antarctic Ice Sheet from 1992 to 2017, Nature, 558, 219-222, https://doi.org/10.1038/s41586018-0179-y, 2018.

Irving, J. D., Knoll, M. D., and Knight, R. J.: Improving crosshole radar velocity tomograms: A new approach to incorporating high-angle traveltime data, Geophysics, 72, 31-41, https://doi.org/10.1190/1.2742813, 2007.

Jacobs, S. S., Helmer, H. H., Doake, C. S. M., Jenkins, A., and Frolich, R. M.: Melting of ice shelves and 
the mass balance of Antarctica, J. Glaciol., 38, 375-387, https://doi.org/10.3189/S0022143000002252, 1992.

Jenkins, A. and Doake, C. S. M.: Ice-ocean interaction on Ronne Ice Shelf, Antarctica, J. Geophys. Res.-Oceans, 96, 791-813, https://doi.org/10.1029/90JC01952, 1991.

Jenkins, A., Corr, H. F. J., Nicholls, K. W., Stewart, C. L., and Doake, C. S. M.: Interactions between ice and ocean observed with phase-sensitive radar near an Antarctic ice-shelf grounding line, J. Glaciol., 52, 325-346, https://doi.org/10.3189/172756506781828502, 2006.

Jenkins, A., Dutrieux, P., Jacobs, S. S., McPhail, S. D., Perrett, J. R., Webb, A. T., and White, D.: Observations beneath Pine Island Glacier in West Antarctica and implications for its retreat, Nat. Geosci., 3, 468, https://doi.org/10.1038/ngeo890, 2010.

Joughin, I. and Vaughan, D. G.: Marine ice beneath the Filchner-Ronne Ice Shelf, Antarctica: a comparison of estimated thickness distributions, Ann. Glaciol., 39, 511-517, https://doi.org/10.3189/172756404781814717, 2004.

Kingslake, J., Ng, F., and Sole, A.: Modelling channelized surface drainage of supraglacial lakes, J. Glaciol., 61, 185-199, https://doi.org/10.3189/2015JoG14J158, 2015.

Kusahara, K. and Hasumi, H.: Modeling Antarctic ice shelf responses to future climate changes and impacts on the ocean Ž, J. Geophys. Res.-Oceans, 118, 2454-2475, https://doi.org/10.1002/jgrc.20166, 2013.

Kwok, R. and Comiso, J.: Southern Ocean Climate and Sea Ice Anomalies Associated with the Southern Oscillation, J. Climate, 15, 487-501, https://doi.org/10.1175/15200442(2002)015<0487:SOCASI >2.0.CO;2, 2002.

Kwok, R., Comiso, J. C., Lee, T., and Holland, P. R.: Linked trends in the South Pacific sea ice edge and Southern Oscillation Index, J. Geophys. Res., 43, 295-302, https://doi.org/10.1002/2016GL070655, 2016.

Langley, K., von Deschwanden, A., Kohler, J., Sinisalo, A., Matsuoka, K., Hattermann, T., Humbert, A., Nøst, O. A., and Isaksson, E.: Complex network of channels beneath an Antarctic ice shelf, Geophys. Res. Lett., 41, 1209-1215, https://doi.org/10.1002/2013GL058947, 2014a.

Langley, K., Kohler, J., Sinisalo, A., Øyan, M. J., Hamran, S. E., Hattermann, T., Matsuoka, K., Nøst, O. A., and Isaksson, E.: Low melt rates with seasonal variability at the base of Fimbul Ice Shelf, East Antarctica, revealed by in situ interferometric radar measurements, Geophys. Res. Lett., 41, 8138-8146, https://doi.org/10.1002/2014GL061782, 2014b.

Lapazaran, J. J., Otero, J., Martín-Español, A., and Navarro, F. J.: On the errors involved in ice-thickness estimates I: ground- penetrating radar measurement errors, J. Glaciol., 62, 1008-1020, https://doi.org/10.1017/jog.2016.93, 2016.

Lenaerts, J. T. M., Brown, J., van den Broeke, M. R., Matsuoka, K., Drews, R., Callens, D., Philippe, M., Gorodetskaya, I. V., van Meijgaard, E., Reijmer, C. H., Pattyn, F., and van Lipzig, N. P. M.: High variability of climate and surface mass balance induced by Antarctic ice rises, J. Glaciol., 60, 1101-1110, https://doi.org/10.3189/2014JoG14J040, 2014.

Lenaerts, J. T. M., Lhermitte, S., Drews, R., Ligtenberg, S. R. M., Berger, S., Helm, V., Smeets, C. J. P. P., van den Broeke, M. R., van de Berg, W. J., van Meijgaard, E., Eijkelboom, M., Eisen, O., and Pattyn, F.: Meltwater produced by wind - albedo interaction stored in an East Antarctic ice shelf, Nat. Clim. Change, 7, 5863, https://doi.org/10.1038/NCLIMATE3180, 2017.

Lindbäck, K., Pettersson, R., Doyle, S. H., Helanow, C., Jansson, P., Kristensen, S. S., Stenseng, L., Forsberg, R., and Hubbard, A. L.: High-resolution ice thickness and bed topography of a land-terminating section of the Greenland Ice Sheet, Earth Syst. Sci. Data, 6, 331-338, https://doi.org/10.5194/essd-6-331-2014, 2014.

Lindbäck, K., Kohler, J., Pettersson, R., Nuth, C., Langley, K., Messerli, A., Vallot, D., Matsuoka, K., and Brandt, O.: Subglacial topography, ice thickness, and bathymetry of Kongsfjorden, northwestern Svalbard, Earth Syst. Sci. Data, 10, 17691781, https://doi.org/10.5194/essd-10-1769-2018, 2018.

Makinson, K. and Nicholls, K. W.: Modeling tidal currents beneath Filchner-Ronne Ice Shelf and on the adjacent continental shelf: Their effect on mixing and transport, J. Geophys. Res.-Oceans, 104, 13449-13465, https://doi.org/10.1029/1999jc900008, 1999.

Malyarenko, A., Robinson, N. J., Williams, M. J. M., and Langhorne, P. J.: A wedge mechanism for summer surface water inflow into the Ross Ice Shelf cavity, J. Geophys. Res.-Oceans, 124, 1196-1214, https://doi.org/10.1029/2018jc014594, 2019.

Marsh, O. J., Fricker, H. A., Siegfried, M. R., Christianson, K., Nicholls, K. W., Corr, H. F. J., and Catania, G.: High basal melting forming a channel at the grounding line of Ross Ice Shelf, Antarctica, Geophys. Res. Lett., 43, 1-6, https://doi.org/10.1002/2015GL066612, 2016.

Matsuoka, K., Pattyn, F., Callens, D., and Conway, H.: Radar characterization of the basal interface across the grounding zone of an ice-rise promontory in East Antarctica, Ann. Glaciol., 53, 29-34, https://doi.org/10.3189/2012AoG60A106, 2012.

Matsuoka, K., Hindmarsh, R. C. A., Moholdt, G., Bentley, M. J., Pritchard, H. D., Brown, J., Conway, H., Drews, R., Durand, G., Goldberg, D., Hattermann, T., Kingslake, J., Lenaerts, J. T. M., Martín, C., Mulvaney, R., Nicholls, K. W., Pattyn, F., Ross, N., Scambos, T., and Whitehouse, P. L.: Antarctic ice rises and rumples: Their properties and significance for icesheet dynamics and evolution, Earth Sci. Rev., 150, 724-745, https://doi.org/10.1016/j.earscirev.2015.09.004, 2015.

McGrath, D., Steffen, K., Scambos, T., Rajaram, H., Casassa, G., and Rodriguez Lagos, J. L.: Basal crevasses and associated surface crevassing on the Larsen $\mathrm{C}$ ice shelf, Antarctica, and their role in ice-shelf instability, Ann. Glaciol., 53, 10-18, https://doi.org/10.3189/2012AoG60A005, 2012.

Millgate, T., Holland, P. R., Jenkins, A., and Johnson, H. L.: The effect of basal channels on oceanic ice-shelf melting, J. Geophys. Res.-Oceans, 118, 6951-6964, https://doi.org/10.1002/2013JC009402, 2013.

Moholdt, G. and Matsuoka, K.: Inventory of Antarctic ice rises and rumples (version 1) [Dataset], Norwegian Polar Intitute, https://doi.org/10.21334/npolar.2015.9174e644, 2015.

Mouginot, J., Scheuchl, B., and Rignot, E.: MEaSUREs Antarctic Boundaries for IPY 2007-2009 from Satellite Radar, Version 2, NASA Natl. Snow Ice Data Cent. Distrib. Act. Arch. Center, https://doi.org/10.5067/AXE4121732AD, 2017.

Mueller, R. D., Padman, L., Dinniman, M. S., Erofeeva, S. Y., Fricker, H. A., and King, M. A.: Impact of tidetopography interactions on basal melting of Larsen $\mathrm{C}$ Ice Shelf, Antarctica, J. Geophys. Res.-Ocean., 117, 1-20, https://doi.org/10.1029/2011JC007263, 2012. 
Mueller, R. D., Hattermann, T., Howard, S. L., and Padman, L.: Tidal influences on a future evolution of the Filchner-Ronne Ice Shelf cavity in the Weddell Sea, Antarctica, The Cryosphere, 12, 453-476, https://doi.org/10.5194/tc-12-453-2018, 2018.

Natural Resources Canada: CSRS-PPP: On-Line GNSS PPP PostProcessing Service, available at: http://webapp.geod.nrcan.gc.ca/ geod/tools-outils/ppp.php (last access: 1 January 2019), 2017.

Nicholls, K. W., Abrahamsen, E. P., Buck, J. J. H., Dodd, P. A., Goldblatt, C., Griffiths, G., Heywood, K. J., Hughes, N. E., Kaletzky, A., McPhail, S. D., Millard, N. W., Oliver, K. I. C., Perrett, J., Price, M. R., Pudsey, C. J., Saw, K., Stansfield, K., Stott, M. J., Wadhams, P., Webb, A. T., and Wilkinson, J. P.: Measurements beneath an Antarctic ice shelf using an autonomous underwater vehicle, Geophys. Res. Lett., 33, L08612, https://doi.org/10.1029/2006GL025998, 2006.

Nicholls, K. W., Corr, H. F. J., Stewart, C. L., Lok, L. B., Brennan, P. V., and Vaughan, D. G.: Instruments and Methods A groundbased radar for measuring vertical strain rates and time-varying basal melt rates in ice sheets and shelves, J. Glaciol., 61, 10791087, https://doi.org/10.3189/2015JoG15J073, 2015.

Norwegian Polar Institute: Norwegian Polar Data Centre, available at: https://data.npolar.no, last access: 1 September 2019.

Nøst, O. A., Biuw, M., Tverberg, V., Lydersen, C., Hattermann, T., Zhou, Q., Smedsrud, L. H., and Kovacs, K. M.: Eddy overturning of the Antarctic Slope Front controls glacial melting in the Eastern Weddell Sea, J. Geophys. Res.-Oceans, 116, 1-17, https://doi.org/10.1029/2011JC006965, 2011.

Paolo, F. S., Fricker, H. A., and Padman, L.: Volume loss from Antarctic ice shelves is accelerating, Science, 348, 327-332, https://doi.org/10.1126/science.aaa0940, 2015.

Pritchard, H. D., Ligtenberg, S. R. M., Fricker, H. A., Vaughan, D. G., van Den Broeke, M. R., and Padman, L.: Antarctic ice-sheet loss driven by basal melting of ice shelves, Nature, 484, 502-505, https://doi.org/10.1038/nature10968, 2012.

Rahman, S.: FMCW Radar Signal Processing for Antarctic Ice Shelf Profiling and Imaging, Unversity College London, 2016.

Reese, R., Gudmundsson, G. H., Levermann, A., and Winkelmann, R.: The far reach of ice-shelf thinning in Antarctica, Nat. Clim. Change, 8, 53-57, https://doi.org/10.1038/s41558-017-0020-x, 2018.

Rignot, E., Mouginot, J., and Scheucht, B.: Ice Flow of the Antarctic Ice Sheet, Science, 333, 1427-1431, https://doi.org/10.1126/science.1208336, 2011.

Rignot, E., Jacobs, S., Mouginot, J., and Scheuchl, B.: IceShelf Melting Around Antarctica, Science, 341, 266-270, https://doi.org/10.1126/science.1235798, 2013.

Rignot, E., Mouginot, J., Scheuchl, B., van den Broeke, M. R., van Wessem, M. J., and Morlighem, M.: Four decades of Antarctic Ice Sheet mass balance from 1979-2017, P. Natl. Acad. Sci. USA, 116, 1095-1103, https://doi.org/10.1073/pnas.1812883116, 2019.

Rintoul, S. R., Silvano, A., Pena-Molino, B., van Wijk, E. Van, Rosenberg, M., Greenbaum, J. S., and Blankenship, D. D.: Ocean heat drives rapid basal melt of the Totten Ice Shelf, Sci. Adv., 2, 1-5, https://doi.org/10.1126/sciadv.1601610, 2016.

Ryan, S., Schröder, M., Huhn, O., and Timmermann, R.: On the warm inflow at the eastern boundary of the Weddell Gyre, Deep-Sea Res. Pt. I, 107, 70-81, https://doi.org/10.1016/j.dsr.2015.11.002, 2016.
Schmidtko, S., Heywood, K. J., Thompson, A. F., and Aoki, S.: Multidecadal warming of Antarctic waters, Science, 346, 12271231, https://doi.org/10.1126/science.1256117, 2014.

Schreiber, T. and Schmitz, A.: Surrogate time series, Physica D, 142, 346-382, https://doi.org/10.1016/S0167-2789(00)00043-9, 2000.

Shepherd, A., Fricker, H. A., and Farrell, S. L.: Trends and connections across the Antarctic cryosphere, Nature, 558, 223-232, https://doi.org/10.1038/s41586-018-0171-6, 2018.

Stanton, T. P., Shaw, W. J., Truffer, M., Corr, H. F. J., Peters, L. E., Riverman, K. L., Bindschadler, R. A., Holland, D. M., and Anandakrishnan, S.: Channelized Ice Melting in the, Science, 341, 1236-1239, https://doi.org/10.1126/science.1239373, 2013.

Stern, A. A., Dinniman, M. S., Zagorodnov, V., Tyler, S. W., and Holland, D. M.: Intrusion of warm surface water beneath the McMurdo ice shelf, Antarctica, J. Geophys. Res.-Oceans, 118, 7036-7048, https://doi.org/10.1002/2013JC008842, 2013.

Stewart, A. L. and Thompson, A. F.: Eddy Generation and Jet Formation via Dense Water Outflows across the Antarctic Continental Slope, J. Phys. Oceanogr., 46, 3729-3750, https://doi.org/10.1175/jpo-d-16-0145.1, 2016.

Stewart, C. L., Christoffersen, P., Nicholls, K. W., Williams, M. J. M., and Dowdeswell, J. A.: Basal melting of Ross Ice Shelf from solar heat absorption in an ice-front polynya, Nat. Geosci., 12, 435-440, https://doi.org/10.1038/s41561-019-0356-0, 2019.

Stuecker, M., Bitz, C., and Armour, K.: Conditions leading to the unprecedented low Antarctic sea ice extent during the 2016 austral spring season, Geophys. Res. Lett., 44, 9008-9019, https://doi.org/10.1002/2017GL074691, 2017.

Sverdrup, H. U.: The Currents off the Coast of Queen Maud Land, Nor. Geogr. Tidsskr.-Nor. J. Geogr., 14, 239-249, https://doi.org/10.1080/00291955308542731, 1954.

Swart, N. C., Gille, S. T., Fyfe, J. C., and Gillett, N. P.: Recent Southern Ocean warming and freshening driven by greenhouse gas emissions and ozone depletion, Nat. Geosci., 11, 836-842, https://doi.org/10.1038/s41561-018-0226-1, 2018.

Taylor, J. R.: An Introduction to Error Analysis: The Study of Uncertainties in Physical Measurements, University of Colorado, 1996.

Thompson, A. F., Heywood, K. J., Schmidtko, S., and Stewart, A. L.: Eddy transport as a key component of the Antarctic overturning circulation, Nat. Geosci., 7, 879-884, https://doi.org/10.1038/ngeo2289, 2014.

Thompson, A. F., Stewart, A. L., Spence, P., and Heywood, K. J.: The Antarctic Slope Current in a Changing Climate, Rev. Geophys., 56, 741-770, https://doi.org/10.1029/2018RG000624, 2018.

Turner, J. and Comiso, J.: Solve Antarctica's sea-ice puzzle, Nature, 547, 275-277, https://doi.org/10.1038/547275a, 2017.

Turner, J., Hosking, J. S., Bracegirdle, T. J., Marshall, G. J., and Phillips, T.: Recent changes in Antarctic Subject Areas, Philos. T. R. Soc. A, 373, 20140163, https://doi.org/10.1098/rsta.2014.0163, 2015.

van de Berg, W. J., van den Broeke, M. R., Reijmer, C. H., and van Meijgaard, E.: Reassessment of the Antarctic surface mass balance using calibrated output of a regional atmospheric climate model, J. Geophys. Res., 111, 1-15, https://doi.org/10.1029/2005JD006495, 2006. 
Vaňková, I., Voytenko, D., Nicholls, K. W., Xie, S., Parizek, B. R., and Holland, D. M.: Vertical Structure of Diurnal Englacial Hydrology Cycle at Helheim Glacier, East Greenland, Geophys. Res. Lett., 45, 8352-8362, https://doi.org/10.1029/2018GL077869, 2018.
Zhou, Q., Hattermann, T., Nøst, O. A., Biuw, M., Kovacs, K. M., and Lydersen, C.: Wind-driven spreading of fresh surface water beneath ice shelves in the Eastern Weddell Sea, J. Geophys. Res.-Oceans, 119, 3818-3833, https://doi.org/10.1002/2013JC009556, 2014. 